\title{
Bacteriophages: \\ Update on application as models for viruses in water
}

\author{
WOK Grabow \\ Department of Medical Virology, University of Pretoria, PO Box 2034, Pretoria 0001, South Africa
}

\begin{abstract}
Phages are valuable models or surrogates for enteric viruses because they share many fundamental properties and features. Among these are structure, composition, morphology, size and site of replication. Even though they use different host cells, coliphages and Bacteroides fragilis phages predominantly replicate in the gastro-intestinal tract of humans and warm-blooded animals where enteric viruses also replicate. A major advantage of phages is that, compared to viruses, they are detectable by simple, inexpensive and rapid techniques. In view of these features, phages are particularly useful as models to assess the behaviour and survival of enteric viruses in the environment, and as surrogates to assess the resistance of human viruses to water treatment and disinfection processes. Since there is no direct correlation between numbers of phages and viruses, phages cannot to a meaningful extent be used to indicate numbers of viruses in polluted water. The presence of phages typically associated with human and animal excreta indicates the potential presence of enteric viruses. However, the absence of these phages from water environments is generally a meaningful indication of the absence of enteric viruses. This is because phages such as somatic coliphages, F-RNA coliphages and $B$. fragilis phages generally outnumber enteric viruses in water environments, and they are at least as resistant to unfavourable conditions including those in water treatment and disinfection processes. However, using highly sensitive molecular techniques viruses have been detected in drinking water supplies which yielded negative results in conventional tests for phages. Initially, data on phages were rather confusing because a wide variety of techniques was used. However, techniques for the detection of phages are being standardised internationally. This applies in particular to somatic and F-RNA coliphages, and B. fragilis phages, which are most commonly used in water quality assessment. Reliable and practical techniques now available include direct quantitative plaque assays on samples of water up to $100 \mathrm{~m} \ell$, and qualitative tests on $500 \mathrm{~m} \ell$ or more using highly sensitive enrichment procedures.
\end{abstract}

\section{Introduction}

Bacteriophages (phages) are viruses which infect bacteria. They were discovered independently by Frederick W Twort in England in 1915 and by Felix d'Herelle at the Pasteur Institute in Paris in 1917 (Pelczar et al., 1988). Phages were the last of the three major classes of viruses to be discovered during World War I. The other two classes were the plant viruses and animal viruses. It was then hoped that their ability to kill bacteria could be used for the prevention and treatment of bacterial disease, but this did not prove successful due to the rapid selection of resistant bacteria (Goyal et al., 1987). However, phages eventually turned out to have major other benefits, notably as models or surrogates for human viruses in basic genetic research as well as water quality assessment.

Phages proved to be most valuable tools in research on viruses because compared with the human, animal, plant and even insect hosts of other viruses, phages are easily and rapidly cultivated in laboratories which are not particularly demanding with regard to space, facilities, and equipment (Pelczar et al., 1988). Research on the basic genetic properties of phages led to the development of an entirely new science - that of molecular biology - which allowed unprecedented advancements in all the biological and medical sciences. In addition, the way all viruses reproduce was first indicated by work with phages (Ackermann, 1969).

\section{Structure and morphology of phages}

Phages basically consist of a nucleic acid molecule (genome) surrounded by a protein coat (capsid). The capsid is made up of

푱(012) 319-2351; fax (012) 325-5550; e-mail: grabow@med.up.ac.za Received 29 February 2000 morphological subunits called capsomeres. The capsomeres consist of a number of protein subunits or molecules called protomers. Some phages also contain lipid and additional structures such as tails and spikes. These features imply that in terms of composition, structure and morphology, phages share many fundamental properties with human viruses. For instance, F-RNA coliphages (Family Leviviridae) and enteroviruses such as polio viruses (Family Picornaviridae) both have an icosahedral capsid with a diameter of about $25 \mathrm{~nm}$ and a single strand (ss)-RNA genome. Under the electron microscope F-RNA coliphages and enteroviruses are hardly distinguishable (Fig. 1). In addition, F-RNA coliphages and enteroviruses are both excreted by humans. For these reasons coliphages are valuable models or surrogates for human enteric viruses. As a result of these similarities, the behaviour of F-RNA coliphages as well as other phages, resembles that of enteric viruses much closer than faecal bacteria such as coliforms commonly used as indicators of faecal pollution. The same applies to properties such as removal by water treatment processes and resistance to disinfection processes. However, there are differences which limit the indicator value of phages. For instance, electrostatic charges on phages may differ from those on enteric viruses, which affect important properties such as adsorption to solid surfaces. This has implications for features like behaviour in the environment, and the efficiency of recovery by techniques based on adsorption-elution principles.

\section{Phage replication}

Phages and enteric viruses can replicate only inside host cells, which in the case of phages are susceptible bacteria, and in the case of enteric viruses are susceptible mammalian cells. Phages use the ribosomes, protein-synthesising factors, amino acids, and energy- 


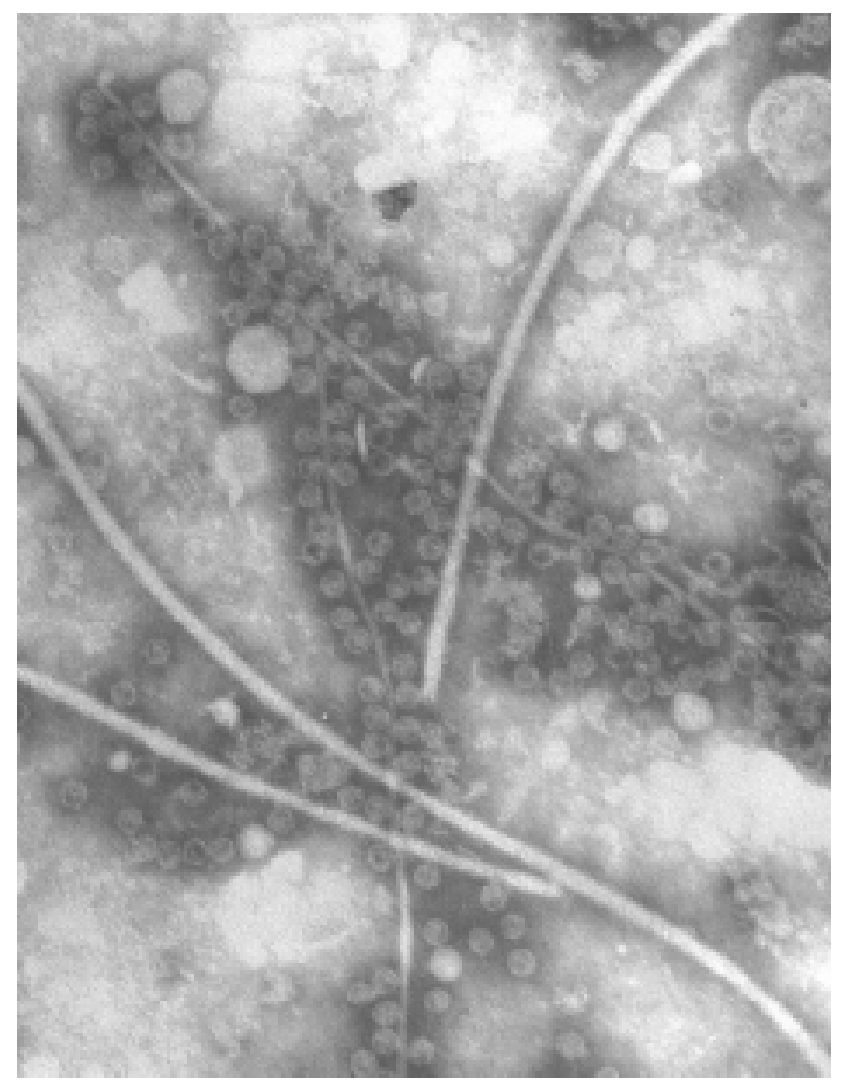

Figure 1

Electron micrograph of F-RNA coliphages (Family Leviviridae). Size of about $25 \mathrm{~nm}$ and morphology are similar to that of human enteroviruses like polio virus. Note attachment of the phages to bacterial fertility fimbriae which have receptor sites for these phages. The thicker rods are bacterial flagellae without receptor sites.

generating systems of the host cell to replicate, and hence, phages can multiply only in metabolising host bacteria (Goyal et al., 1987). Some phage species have fewer than 10 genes and use almost all of the cellular functions, whereas others have 30 to 100 genes and are less dependent on the host. A few of the large phage particles have so many of their own genes that, for certain functions such as DNA replication, they need no host genes (Freifelder, 1987). Phages can only infect certain bacteria. The host-specificity of phages is determined by receptor sites (protein molecules) on the surface of bacteria. Only certain phages will recognise these receptor sites and attach to them which leads to infection of the bacterium (Goyal et al., 1987).

Phage receptor sites are located on different parts of bacteria. Some of them are located on the cell wall and are present all the time. These receptor sites are typically recognised by phages known as somatic phages. This implies that somatic phages can infect host bacteria at any time, and somatic phages will even attach to dead host bacteria. Somatic phages typically include members of the families Myoviridae, Siphoviridae, Podoviridae and Microviridae. Receptor sites for other phages are located on, for instance, the fertility (sex) fimbriae of host bacteria. These fimbriae are produced only by bacteria in the logarithmic growth phase under optimal growth conditions. In the case of Escherichia coli fertility fimbriae are produced only at temperatures well above $30^{\circ} \mathrm{C}$. Phages which typically utilise these receptor sites are known as male-specific phages and include members of the families
Inoviridae and Leviviridae. These features have major implications for the utilisation of phages as models/surrogates for human viruses. For instance, under certain optimal conditions host bacteria, notably heterotrophic bacteria, may support the replication of somatic phages in water environments. However, in environmental waters, even in sewage, conditions rarely if ever meet requirements for the production of fertility fimbriae. An important limiting factor is the temperature of at least $30^{\circ} \mathrm{C}$. This implies that for all practical purposes replication of male-specific phages in environmental waters is most unlikely, while somatic coliphages may under circumstances multiply in certain water environments (Grabow et al., 1980).

Optimal conditions for the replication of both somatic and male-specific phages typically prevail in the gastro-intestinal tract of humans and other warm-blooded animals. Since human enteric viruses are released into the environment almost exclusively from the gastro-intestinal tract of humans, phages which infect typical enteric bacteria such as $E$. coli, resemble human viruses with regard to origin and release into the environment. This strongly supports the value of phages, notably coliphages and Bacteroides fragilis phages, as models/surrogates for enteric viruses.

Among phages, the F-RNA male-specific phages are theoretically probably the best models/surrogates for enteric viruses because: like enteric viruses they almost exclusively originate from the faeces of humans and other warm-blooded animals; like enteric viruses they fail to multiply in the environment; and in terms of composition, structure and size they closely resemble human enteric viruses.

However, coliphages are excreted at all times by a certain percentage of all humans and other warm-blooded animals (Grabow et al., 1995), whereas enteric viruses of human health concern are excreted almost exclusively by humans during infection which may last for a few days to a few weeks. This implies that the incidence of human enteric viruses in the environment is subject to variables such as the epidemiology of viral infections, outbreaks of infections in communities, vaccination against viruses, seasonal changes, and other variables which do not affect the excretion of coliphages. In addition, human enteric viruses and coliphages are not excreted in the same numbers and not for the same periods of time. Consequently there is rarely, if ever, a direct correlation between the numbers of any coliphages and any enteric viruses in water environments at any time.

Phages are divided into two groups according to their mode of replication. Virulent (lytic) phages typically proceed with replication immediately after infecting the host cell and new viruses are released in large numbers by rupture (lysis) of the host cell within as little as $30 \mathrm{~min}$ after infection. These phages typically produce clear plaques on a lawn of susceptible host bacteria because all bacteria in the area of infection are destroyed (Davis et al., 1990). Temperate (lysogenic) phages do not necessarily start replicating immediately. Depending on a number of conditions, these phages may integrate their nucleic acid (genome) into that of the host cell where it remains until induced to become autonomous again and start replication and cell lysis (Brock and Madigan, 1988). The phage genome may also replicate autonomously in the cytoplasm of host cells without the production of new complete phage particles and lysis of the host cell. These autonomously replicating genetic phage elements are known as plasmids or episomes (Hayes, 1968).

As part of the process of lysogenic infection, phages may convey new properties to the host bacteria. Phages which display this feature include those which code for the production of toxins. They convert normally harmless bacteria into pathogens, such as 
the shiga toxin-converting phages involved in the pathogenicity of E. coli O157:H7 (Muniesa and Jofre, 1998, 2000; Nataro and Kaper, 1998). Several other phages likewise convert harmless bacteria into life-threatening pathogens (Hayes, 1968). This implies that although phages are not able to infect humans themselves, they play an important role in infectious diseases. It may, therefore, be argued that the absence of phages from water intended for human consumption is as desirable as the absence of human viruses (Muniesa and Jofre, 1998; Muniesa et al., 1999).

Various agents or conditions such as ultraviolet light irradiation and a number of chemical agents induce the genome of lysogenic phages or plasmids to code for the production of new phages. Generally, these phages are released at low frequency with limited impact on host populations. Consequently, these phages produce faint or mottled plaques because many host bacteria in the plaque area remain viable and intact (Hayes, 1968).

The host-specificity of phages proved to be a most useful tool for the classification of certain bacteria. Phages may not only be specific for species of bacteria, but also for strains of bacteria, allowing typing beyond the level of species. For instance, Escherichia coli $\mathrm{O} 157: \mathrm{H} 7$ has been sub-divided into 66 different phage types (Frost et al., 1993). Phage typing played a major role in studies on the epidemiology of E. coli O157:H7 infections. Phage typing is relatively easy to perform and allows large numbers of bacterial isolates to be analysed (Strockbine et al., 1998). This method of typing has also been applied to a number of other bacteria.

\section{Phage classification}

\section{Phage taxonomy}

Adams (1953a) was the first phage taxonomist of note. He considered all the available criteria for classification and concluded that a Linnaean system, although desirable, was premature. He also warned against grouping phages together with other viruses because doing so would imply a common origin.

Phages are associated with almost all bacterial genera, including the cyanobacteria, archaebacteria and mycoplasmas. Phages may readily be grouped on the basis of a few gross characteristics including (Abeles et al., 1984): host range, morphology, nucleic acid, strategies of infection, morphogenesis, phylogeny, serology, sensitivity to physical and chemical agents, and dependence on properties of hosts and the environment.

Goyal et al.(1987) classified phages into three groups according to location of receptor sites on the following parts of host bacteria:

- appendages such as pili and flagella (appendage phages),

- outer layer such as the polysaccharide capsule (capsule phages),

- cell wall (somatic phages).

Phages of particular interest in water quality assessment are currently classified into the following six families, primarily according to morphology and nucleic acid content (Pelczar et al., 1988; Maniloff and Ackermann, 1998) (Fig. 2):

- Myoviridae:

Cubic capsid (icosahedral or elongated), linear double-stranded (ds) DNA, long contractile tail.

Typical members: Coliphages T4, P1 and Mu.

- Siphoviridae (Stylovirudae):

Cubic (icosahedral) capsid, linear dsDNA, long non-contractile tail.
Typical members: Coliphages T5 and 1.

- Podoviridae:

Cubic (Icosahedral) capsid, linear dsDNA, short non-contractile tail.

Typical members: Coliphage T7 and enterobacter phage P22.

- Microviridae:

Cubic (icosahedral) capsid, circular single-strand (ss) DNA, no tail.

Typical member: Coliphage $\mathrm{fX} 174$.

- Inoviridae:

Filamentous or rod-shaped, circular ssDNA, no tail.

Typical member: Coliphage f1, fd and M13.

- Leviviridae:

Cubic (icosahedral) capsid, linear ssRNA, no tail.

Typical members: enterobacteriophages MS2 and Qß.

In addition, there is a number of other families such as Cystoviridae (enveloped, icosahedral capsid with segmented dsRNA), Lipothrixviridae (enveloped rod-shaped capsid with linear dsDNA), Corticoviridae (lipid-containing icosahedral capsid with circular dsDNA) and Tectiviridae (lipid-containing double icosahedral capsid with linear dsDNA), Plasmaviridae (enveloped pleomorphic capsid with circular dsDNA), Rudiviridae (non-enveloped rodshaped capsid with linear dsDNA) and Fuselloviridae (nonenveloped lemon-shaped capsid with circular dsDNA) .

Members of most of the families of phages have been detected in a wide variety of water environments (Spencer, 1955; Ackermann and Nguyen, 1983; Tartera and Jofre, 1987; Havelaar et al., 1990; Grabow et al., 1993, 1998; Pedroso and Martins, 1995).

\section{Phages commonly used as models/surrogates in water quality assessment}

\section{Somatic coliphages}

This term refers to a wide spectrum of lytic members of the families Myoviridae, Siphoviridae, Podoviridae and Microviridae that infect E. coli and certain closely related members of the bacterial family Enterobacteriacea (Hayes, 1968). Some of these hosts may multiply or metabolise in water environments to the extent that they support the replication of somatic coliphages. In other words, counts of somatic coliphages may increase in certain water environments (Grabow 1990; Grabow et al., 1998). Somatic coliphages have been found to generally outnumber F-RNA phages in waste water and raw water sources by a factor of about 5 , and cytopathogenic human viruses by about 500 (Grabow et al., 1993). Somatic coliphages are, therefore, useful indicators of the potential presence of enteric viruses in water environments, and valuable models/ surrogates for assessing the behaviour of enteric viruses in water treatment and disinfection processes (Grabow, 1990; Grabow et al., 1999b). Somatic coliphages are detectable by relatively simple, inexpensive and rapid plaque assays (Grabow et al 1998; ISO, 1998a; Standard Methods, 1998; Green et al., 2000).

\section{Male-specific F-RNA coliphages}

F-RNA coliphages are ss-RNA phages which represent the simplest phages and so constitute a convenient model system for observing biological events such as viral adsorption and penetration, replication 


\section{FAMIIES OF VIRUSES INFECTING B ACTERIA}

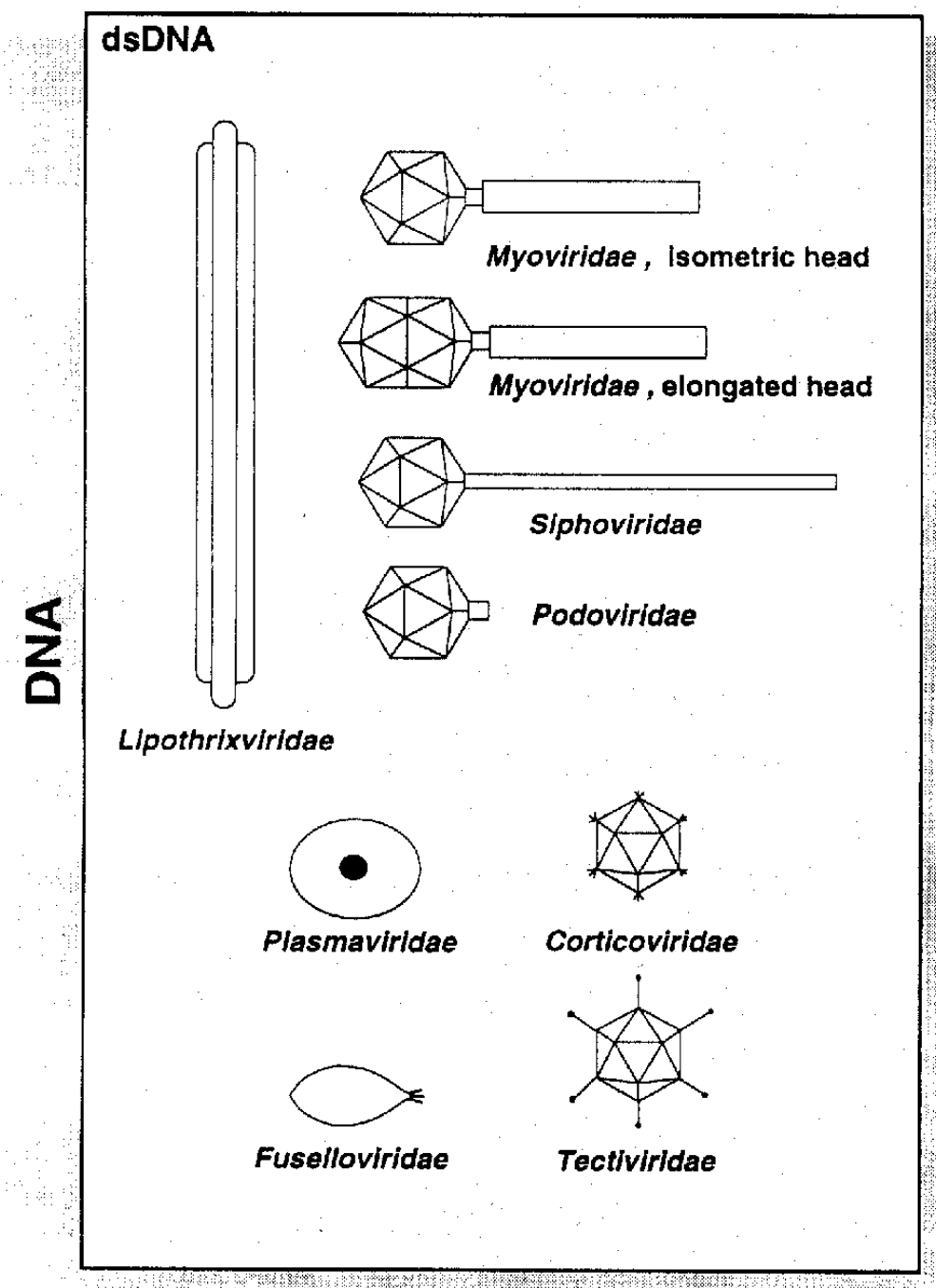

ssDNA

0

Microviridae
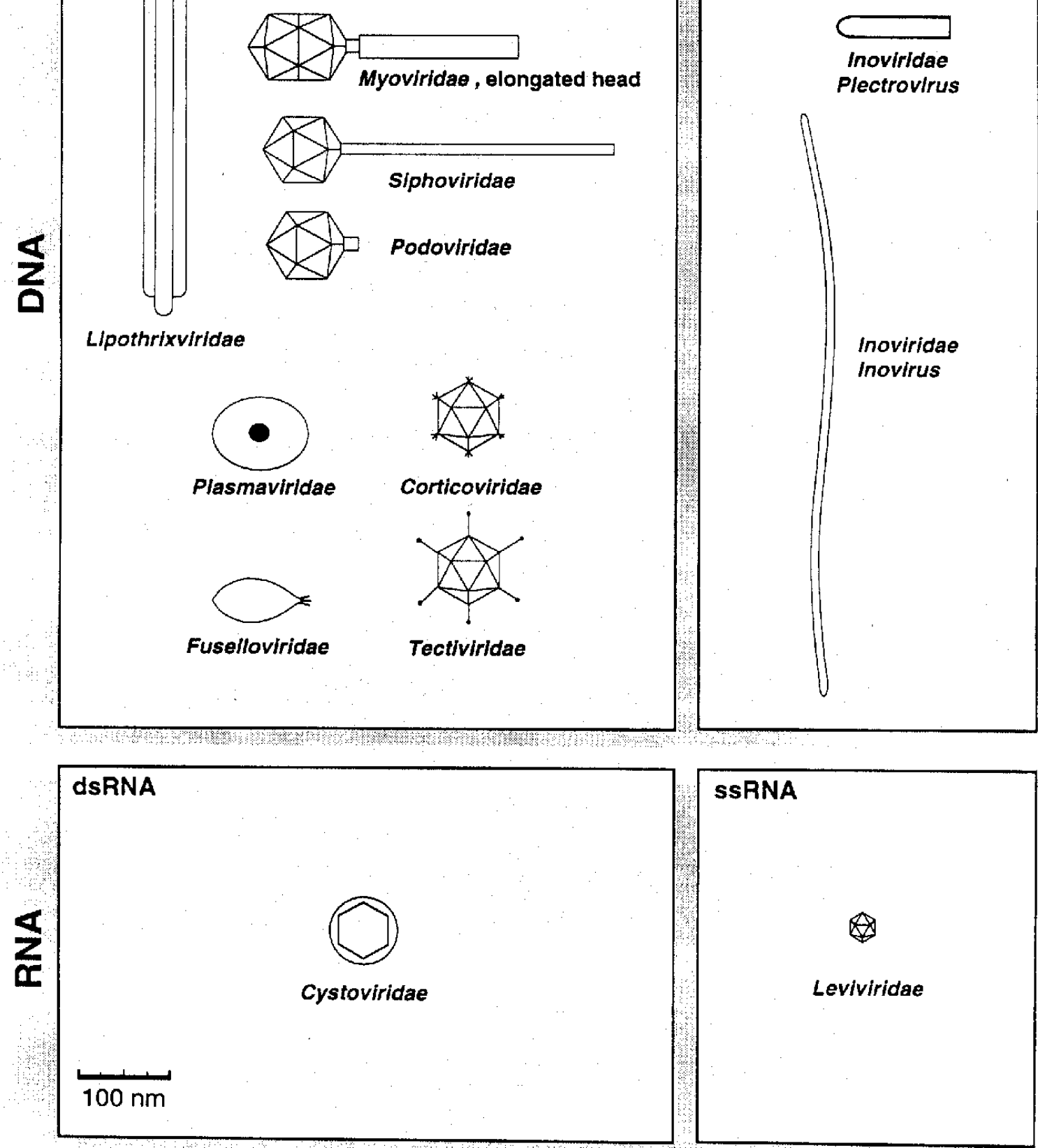

ssRNA

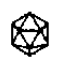

Leviviridae

Figure 2

Diagrammatic illustration of the basic structure of families of bacteriophages (from Murphy et al., 1995). 
and translation of the viral genome, assembly, and viral release (Strauss and Sinsheimer, 1963). The F-specific phages adsorb specifically to Fertility (F) fimbriae (sex-pili) coded by the Fplasmid of E. coli $\mathrm{K}-12$ and related plasmids of the IncFincompatibility group (Havelaar and Pot-Hogeboom, 1988). FRNA coliphages are classified into four serological types. F-RNA coliphages isolated in the USA during the early 1960 s belong to group 1, whereas those isolated in Japan belong to groups 2, 3 and 4. F-RNA phage MS-2 (ATCC 15597-B1) (Havelaar and Hogeboom, 1984), is a member of serogroup 1 and generally used as typical member of the group (Havelaar and Pot-Hogeboom, 1988; ISO, 1995; Grabow et al., 1998). The entire genome of MS2 coliphage has been sequenced. It is a positive-sense ss-RNA molecule of 3569 nucleotides (Bulmer, 1989). The icosahedral protein shell with triangulation number $\mathrm{T}=3$ is composed of 180 copies of the coat protein (relative molecular mass $M_{r} 13700$ ); the virion also contains one copy of a maturation protein (the Aprotein; $M_{r} 44000$ ) (Atkins et al., 1979; Beremand and Blumenthal, 1979; Goyal et al., 1987). The coat protein (capsid) serves to protect the RNA and acts as a translational repressor of the phageencoded replicase gene (Sugiyama and Nakada, 1970).

The host-range of pilus-specific phages is not necessarily restricted to one or a few closely related species. Production of pili is usually encoded on the $\mathrm{F}$ (fertility) plasmid and the host-range of pilus-dependent phages depends primarily on the successful transfer and expression of the plasmid. Since F-encoded pili are only synthesised at temperatures above $30^{\circ} \mathrm{C}$, F-RNA phages are not likely to replicate in environments other than the gastro-intestinal tract of warm-blooded animals. The F-plasmid of $E$. coli $\mathrm{K}-12$ has successfully been transferred to Salmonella typhimurium, as well as Shigella and Proteus species, causing the recipient cells to become susceptible to male-specific coliphages (Birge, 1981).

An interesting and valuable feature of F-RNA phages is that the four serogroups are selectively excreted by humans or animals. Serogroups I and IV have to date been found exclusively in animal faeces, and serogroup III phages in human faeces. Serogroup II phages have been detected in human faeces and in no animal faeces other than $28 \%$ of porcine faeces. This phenomenon, which is not fully understood, offers an attractive tool to distinguish between faecal pollution of human and animal origin (Furuse et al., 1973, 1983; Osawa et al., 1981; Hsu et al., 1995; Beekwilder et al., 1996; Grabow et al., 1998; Hayward, 1999; Uys, 1999).

F-RNA coliphages have particularly attractive features as models/surrogates of human enteric viruses because their physical structure, composition and morphology closely resemble those of many human enteric viruses. Other valuable features of these phages resembling those of human viruses include their failure to multiply in water environments. In addition, many experiments confirmed that the resistance of F-RNA coliphages to unfavourable conditions and disinfection processes resembles or exceeds that of most human enteric viruses (Grabow, 1990; IAWPRC, 1991; Havelaar et al., 1993). Data on the resistance of F-RNA phages to the following have been recorded: various chemicals (Shah and McCamish, 1972; Bitton, 1987; Snead et al., 1980), heat treatment (Burge et al., 1981), sunlight (Kapuscinski and Mitchell, 1983), ultraviolet light (Harm, 1980; Havelaar et al., 1990), chlorination (Grabow et al., 1983) and water treatment processes (Grabow, 1990; Olivieri et al., 1999).

In a survey of a range of waste waters and raw water sources, F-RNA phages have been found to outnumber cytopathogenic enteric viruses by a factor of about 100 (Grabow et al., 1998). This implies that the absence of F-RNA phages from raw and treated water supplies offers a meaningful indication of the absence of human enteric viruses (Havelaar and Nieuwstad, 1985; IAWPRC, 1991).

Detection of F-RNA coliphages by plaque assays is not as easy and simple as in the case of somatic coliphages. The reason is that the F fimbriae with receptor sites for the phages are produced only by host bacteria in the logarithmic growth phase. This implies that the preparation of host cultures for plaque assays has to be timed carefully to have the host bacteria in the logarithmic growth phase. Even then the plaques are relatively small and mottled because many bacteria in the plaque area are not lysed. Successful plaque assay procedures have been formulated but it is essential to closely follow the instructions (Havelaar and Hogeboom, 1984; ISO, 1995; Grabow et al., 1998).

\section{Bacteroides fragilis phages}

Phages infecting obligate anaerobic bacteria which constitute a major component of the natural flora of the human gastrointestinal tract have been reported. Among these are phages which infect Bacteroides species, notably B. fragilis (Nacescu et al., 1972; Keller and Traub, 1974; Booth et al., 1979; Kai et al., 1985; Jofre et al., 1989; Tartera and Jofre, 1987; Tartera et al., 1989). The genus Bacteroides is found in the human gastrointestinal tract in large numbers (more than $10^{9}-10^{10} / \mathrm{g}$ faeces) in comparison to coliform bacteria which range from $10^{6}-10^{8} / \mathrm{g}$ (Geldreich, 1978; Salyers, 1984). In contrast to coliform bacteria and many other commonly used bacterial indicators of water quality (Grabow, 1996), Bacteroides bacteria themselves have limited value as indicators because they are Gram-negative bacteria which produce no spores, and they are rapidly inactivated by environmental oxygen levels. However, the phages of Bacteroides bacteria are resistant to unfavourable conditions and may, therefore, prove to be valuable indicators (Tartera and Jofre, 1987; Tartera et al., 1988; Jofre et al., 1986, 1995). Even when using B. fragilis indicator strains with a relatively broad phage susceptibility, the percentage of individuals in human populations which excrete these phages has been reported to be only $5 \%$ (Kai et al., 1985) to $10 \%$ (Tartera and Jofre, 1987). The failure of $B$. fragilis phages to multiply in the environment counts in their favour with regard to utilisation as models/surrogates for human enteric viruses.

Compared to coliphages and enteric viruses, $B$. fragilis phages proved relatively resistant to unfavourable conditions, at least in certain water environments (Tartera et al., 1988; Tartera and Jofre, 1989; Jofre et al., 1989). These findings support their value as models/surrogates for the potential presence of enteric viruses in water environments, and as models/surrogates to assess the survival of enteric viruses in water treatment and disinfection processes.

Plaque assays for B. fragilis phages are more complicated, expensive, labour-intensive and time-consuming than those for somatic and F-RNA coliphages. Rather complex growth media supplemented with antibiotics are required, and plates have to be incubated under strictly anaerobic conditions. Theoretically, waste waters may be expected to contain higher levels of $B$. fragilis phages than those on record. The reason for the discrepancy may largely be due to failure of maintaining sufficiently anaerobic conditions during the performance of plaque assays. Details on plaque assays for $B$. fragilis phages have been recorded (Tartera et al., 1992; ISO, 1998b). A molecular procedure based on the polymerase chain reaction (PCR) for the detection of $B$. fragilis HSP40 phages proved to be more sensitive than plaque assays and yielded higher counts of the phages in sewage as well as river- and sea-water (Puig et al., 2000). 


\section{Phage ecology}

A wide variety of phages occur in many water environments (Goyal et al., 1987). Apart from phages in human and animal wastes, large numbers of phages also infect bacteria which form part of the natural flora of fresh water and marine environments (Bergh et al., 1989).

\section{Phages of human and animal origin in water environments}

\section{Replication}

Phages which infect bacterial members of the intestinal flora of humans and animals adsorb and replicate optimally at body temperature which is about $37^{\circ} \mathrm{C}$ for humans and most animals concerned. For instance, F-RNA coliphages can infect host bacteria only at temperatures above $30^{\circ} \mathrm{C}$, and not at all at lower temperatures (Havelaar and Pot-Hogeboom, 1988). Seeley and Primrose (1980) suggested the following classification of coliphages according to the effect of temperature on their efficiency of plating:

- low-temperature (LT) phages with optimum plating temperatures at or below $30^{\circ} \mathrm{C}$

- mid-temperature (MT) phages in the range of 15 to $42^{\circ} \mathrm{C}$

- high-temperature (HT) phages in the range of 25 to $42^{\circ} \mathrm{C}$ or 30 to $45^{\circ} \mathrm{C}$

Some faecal coliform bacteria closely related to E. coli, notably Klebsiella species, are heterotrophic and multiply in certain water environments. This implies that they can support the replication of somatic coliphages under suitable conditions. For instance, counts of somatic coliphages have been found to increase in sand filters and biologically active carbon filters (Grabow, 1990). However, it is most unlikely that conditions in water environments may approach those required for the replication of F-RNA coliphages. This refers particularly to the temperature of at least $30^{\circ} \mathrm{C}$ which is required for the production of the $\mathrm{F}$ fimbriae on which the receptor sites for the phages are located. Likewise, it is most unlikely that $B$. fragilis phages can multiply in water environments. Most important reasons are that the hosts are metabolically active only under strictly anaerobic conditions, and the hosts are rapidly inactivated in water environments.

The presence of organic matter plays an important role in the replication of phages since it affects the metabolic activity of host bacteria. According to Goyal et al. (1980) S. typhi is capable of producing phage titres of $10^{9}-10^{10}$ per $\mathrm{m} \ell$ in both laboratory media and sewage.

Cations such as calcium and magnesium ions, promote phage adsorption to host bacteria (Havelaar and Hogeboom, 1983). The $\mathrm{pH}$ of water would not appear to have a major effect on phage adsorption and replication (Goyal et al., 1987).

The numbers of phages and their host bacteria are an important factor in the replication of phages. At low levels of host bacteria, the probability of a phage encountering a susceptible host is low and productive infection may not occur. Bacteria in fresh water environments may be under more nutrient-limiting conditions and may be concentrated at the surface of solids rather than in the overlaying water (Goyal et al., 1987). Evidence has been presented that successful phage replication requires at least $10^{4}$ host bacteria per $\mathrm{m} \ell$ (Goyal et al., 1987).

Tartera et al. (1989) studied the ability of phage B40-8, typespecific phage for $B$. fragilis HSP40, to replicate at either 22 or
$30{ }^{\circ} \mathrm{C}$ in fresh water and sediment samples in the presence of host bacteria. No increase in phage numbers was observed under either aerobic or anaerobic conditions.

\section{Survival}

Factors which affect the numbers and behaviour of phages in water environments include: The densities of both host bacteria and phages; the association of phages and bacteria with solids; the presence of organic matter, especially organic matter that influences the metabolic activity of the host bacteria; ultraviolet and visible light; temperature; $\mathrm{pH}$; the concentration and type of ions; and the metabolic activities of micro-organisms other than the host bacteria. The effects of several of these variables on phage survival have been studied under laboratory conditions. Less information is available on the survival of phages in the environment (Goyal et al., 1987).

Yates et al. (1985) found that the survival of viruses in ground water did not correlate with the $\mathrm{pH}$, nitrate concentration, turbidity, or hardness of water samples obtained from several sources in the United States. Temperature was the only variable that correlated with the survival of phage MS2. Niemi (1976) also reported that the survival of phage $\mathrm{T} 7 \mathrm{in}$ river, lake and ground water was related to the temperature of the water.

Organic compounds which affect phage survival in water environments include humic and fulvic acids, which may influence the attachment of phages to sediments and other solids, and possibly also to their host bacteria. Humic acids influence the attachment of enteroviruses to microporous filters (Sobsey and Hickey, 1985). Fulvic acid was found to complex with viruses and reduce their ability to adsorb to soils (Bixby and O'Brien, 1979).

As a result of the many variables which affect the survival and replication of phages, it is generally difficult to predict the incidence and behaviour of phages in water environments.

\section{Phages in water environments}

Studies on the incidence of phages in water environments have been reported from most parts of the world for some decades now. Unfortunately, the data are not particularly consistent and meaningful comparison is not always possible. One reason is the many variables mentioned above which affect the incidence, survival and behaviour of phages in different water environments. However, another important reason is inconsistency in techniques used for the recovery of phages from water environments, and eventual detection and enumeration of the phages (Green et al., 2000). This is not altogether surprising because virology, including phages, is a young and rapidly developing science. Phages can be recovered and detected by many techniques and approaches, and much of the work along these lines is still in a research or developmental stage. A major reason for discrepancies in results is host bacteria used for the detection of various groups of phages. However, findings from many parts of the world and international collaboration are now precipitating into meaningful, universally-accepted guidelines for the recovery and detection of phages in water environments.

\section{Incidence of phages in water environments}

\section{Fresh water}

Most data on the incidence of phages in water environments are on somatic coliphages. This is largely because somatic coliphages are detectable by simple, inexpensive and rapid techniques, and the phages occur in large numbers in any water environment exposed 
to human or animal excreta. Data on the incidence of somatic coliphages in fresh water environments have been recorded by many authors, including Hilton and Stotsky (1973), Kenard and Valentine (1974), Primrose and Day (1977), Seeley et al. (1979), Logan et al. (1980), Bitton et al. (1981), Simkova and Servenka (1981), Grabow et al. (1984, 1993, 1998), Kennedy et al. (1985), Shields and Farrah (1986), Scheuerman et al. (1987) and Araujo et al. (1997). Counts of somatic and F-RNA phages as high as $10^{5}$ per litre have been recorded for lake and river water. Although limited information is available, phages which infect Klebsiella pneumoniae and Salmonella species have been recovered from fresh water (Goyal et al., 1987). Some coliform bacteria closely related to E. coli, notable Klebsiella species, are heterotrophic and may support the replication of somatic coliphages in natural water environments. Tartera et al. (1989) recorded a mean count of 67 Bacteroides fragilis phages per litre in a sewage-polluted river.

\section{Sea water}

Coliphages and B. fragilis phages which originate from human and animal wastes have been detected in sea water (Tartera and Jofre, 1987; Grabow et al., 1989, 1999c; IAWPRC,1991; Kfir et al., 1991). Factors which influence the survival of phages in marine environments include the ionic environment, temperature, hydrostatic pressure, anaerobic conditions, and host bacteria (Goyal, 1980).

\section{Shellfish}

Bivalve molluscs such as oysters and mussels feed by filtering large volumes of seawater, up to 20 litres per hour. In this process they accumulate viruses and other micro-organisms together with food particles. Numbers of micro-organisms in the gastro-intestinal tract of bivalves may, therefore, exceed those in the surrounding water by several orders of magnitude. Consequently, it is not surprising that intestinal infections are more often associated with the consumption of filter feeders than any other seafood (Grabow et al., 1999c).

Enteric viruses and phages are not released as readily as faecal bacteria by filter feeders depurated in clean water. De Mesquita (1988) detected virtually no reduction in counts of F-RNA and somatic coliphages in shellfish within $72 \mathrm{~h}$, but a 1-3 log reduction of $E$. coli, faecal streptococci and spores of clostridia. Consequently, tests for faecal bacteria such as coliforms often fail to indicate the presence of viruses in shellfish meat (Goyal et al., 1987; Grabow et al., 1989, 1999c; West, 1989). Vaughn and Metcalf (1975) demonstrated that the retention of coliphage T4 by oysters suspended in clean estuarine waters was similar to that of a typical entero virus, namely coxsackie virus B3. Phages are, therefore, most valuable tools for the assessment of the virological safety of shellfish intended for human consumption (Grabow et al., 1999c).

\section{Sewage}

A wealth of information is available on phages in sewage. Counts of somatic coliphages of the order of $10^{6}-10^{8}$ per litre have been recorded by many authors (Bell, 1976; Ignazzitto et al., 1980; Havelaar and Hogeboom, 1984; Havelaar et al., 1984; Tartera et al., 1989; Grabow et al., 1993). Slaughterhouse waste water has been found to contain counts of somatic coliphages as high as $10^{10}$ per litre (Tartera et al., 1989). Counts of F-RNA coliphages are generally on average two to five times lower (Dhillon et al., 1970; Furuse et al., 1973; Dhillon and Dhillon, 1974; Furuse et al., 1973; Grabow et al., 1980; Havelaar and Hogeboom, 1984; Havelaar et al., 1984, 1990; Havelaar and Pot-Hogeboom, 1988; Debartolomeis and Cabelli, 1991; IAWPRC, 1991; Kfir et al., 1991). As mentioned earlier, results from different laboratories tend to differ extensively. This is predominantly because the incidence and survival of phages in sewage is subject to many variables, and different techniques were used to count the phages. In an electron microscopic analysis of sewage Ewert and Paynter (1980) detected more than $10^{11}$ phages per litre, which suggested that coliphages represented about $3,8 \%$ of the total population of phages in the sewage concerned.

Tartera et al. (1989) recorded B. fragilis HSP40 phage counts of up to $4 \times 10^{5}$ per litre in Barcelona sewage. Virtually none of these phages were detected in slaughterhouse waste water, which supports the specificity of the phages for human excreta. Similar findings were reported for waste waters in South Africa (Grabow et al., 1993, 1995). Bacteroides fragilis strain RYC2056, which is susceptible to a wider spectrum of phages, would probably yield higher counts of $B$. fragilis phages in sewage and polluted water environments than strain HSP40 (Puig et al., 1999).

\section{The value of phages as models/surrogates for enteric viruses}

The above features of phages theoretically support their value as models/surrogates for enteric viruses in water environments. This conclusion is based particularly on structure, composition, size and mode of replication which resemble enteric viruses much closer than commonly used bacterial indicators of faecal pollution such as coliforms and enterococci (Coetzee, 1962; Vaughn and Metcalf, 1975; Dhillon et al., 1976; Marzouk et al., 1980; Primrose et al., 1982; Borrego et al., 1983; Goyal et al., 1983; Kott, 1984; Havelaar et al., 1986; Borrego et al., 1987; Goyal et al., 1987; Tartera et al., 1989; IAWPRC, 1991; Payment and Franco, 1993; Grabow, 1996). Inversely, phages may for the same reasons not be the models/ surrogates of choice for the wide variety of other pathogens associated with water-borne transmission.

In addition, phages closely meet the following basic requirements of models/surrogates for enteric viruses (Kott, 1981; Grabow, 1986):

- they should be present in water environments whenever enteric viruses are present,

- they should be present in the same or higher numbers than viruses,

- they should be at least as resistant as viruses to water purification and disinfection processes,

- they should be specific for faecal or sewage pollution,

- they should preferably not be able to multiply in water environments,

- they should preferably be non-pathogenic and detectable by simple, rapid and inexpensive methods.

The value of phages as models/surrogates for enteric viruses is also supported by many laboratory experiments and field studies. Guelin (1948) probably was the first to recommend the use of phages as models/surrogates on the basis of results obtained in studies on phages in fresh and marine waters. Since then laboratory experiments with individual coliphages confirmed that many of them survive longer in natural water environments than enteric viruses and are at least as resistant to commonly-used disinfectant such as chlorine (Kott et al., 1974; Simkova and Cervenka, 1981; Stetler, 1984; Yates et al., 1985; Grabow, 1986). Similar findings have been recorded in detailed studies on phages and viruses in advanced treatment trains for the direct reclamation of drinking water from waste water (Grabow, 1990). Tartera et al. (1988) found $B$. fragilis phage $\mathrm{B} 40-8$ to be more resistant to inactivation 
by chlorine than poliovirus type 1 , simian rotavirus SA11, coliphage f2, Escherichia coli and Streptococcus faecalis.

The value of phages as models/surrogates for viruses has been applied in the routine monitoring of raw and treated drinking water supplies (Grabow et al., 2000), and in the assessment of the efficiency of domestic point-of-use water treatment units (Grabow et al., 1999b).

Although the value of phages as indicators/models/surrogates of enteric viruses is fully appreciated and well-confirmed, there is also sound evidence that phages have certain shortcomings for this purpose. Major considerations in this regard include:

- Phages are excreted by a certain percentage of humans and animals all the time while viruses are excreted only by infected individuals for a short period of time. The excretion of viruses depends heavily upon variables such as the epidemiology of various viruses, outbreaks of viral infections and vaccination against viral infections (Grabow et al., 1999a). Consequently, there is no direct correlation in numbers of phages and viruses excreted by humans (Vaughn and Metcalf, 1975; Borrego et al., 1990; Grabow et al., 1993).

- Methods for somatic coliphages detect a wide range of phages with different properties (Yates et al., 1985; Gerba, 1987).

- At least some somatic coliphages may replicate in water environments (Seeley and Primrose, 1980; Grabow et al., 1984; Borrego et al., 1990).

- Enteric viruses have been detected in water environments in the absence of coliphages (Montgomery, 1982; Deetz et al., 1984; Morinigo et al., 1992).

- Human enteric viruses associated with water-borne diseases are excreted almost exclusively by humans (Grabow, 1996). Phages used as models/surrogates in water quality assessment are excreted by humans and animals. In fact, the faeces of animals such as cows and pigs generally contains higher densities of coliphages than that of humans (Dhillon et al., 1976; Osawa et al., 1981; Furuse et al., 1983), and the percentage of many animals which excrete phages tends to be higher than for humans (Grabow et al., 1993; 1995).

- The microflora of the gut, diet, and physiological state of animals seems to affect the numbers of coliphages in faeces. Osawa et al. (1981) found a higher percentage of stools from zoo animals positive for phages than from domestic farm animals.

- The composition and numbers of phages excreted by humans is variable. Patients under antibiotic treatment were found to excrete lower numbers of phages than comparable patients and healthy individuals who were not exposed to antibiotics (Furuse et al., 1983).

- Differences between phages and enteric viruses are also reflected by differences in the efficiency of adsorption-elution techniques for their recovery discussed elsewhere. These differences are due to differences in adsorption properties, which have major implications for behaviour in water environments and at least some treatment processes.

As a result of the above variables phages cannot be regarded as absolute indicators, models or surrogates for enteric viruses in water environments. This is underlined by the detection of enteric viruses in treated drinking water supplies which yielded negative results in tests for phages, even in presence-absence tests on $500 \mathrm{~m} \ell$ samples of water (Grabow et al., 2000). Phages are probably best applied as models/surrogates in laboratory experiments where the survival or behaviour of selected phages and viruses are directly compared under controlled conditions (EPA, 1986; Grabow et al., 1983, 1999b; Naranjo et al., 1997).

In the assessment of the virological quality of water in treatment plants or water environments with an unknown composition of phages and viruses, phages are probably best applied as part of a combination of indicator organisms selected for the particular purpose concerned (Payment et al., 1985, 1993; Grabow, 1990).

\section{Methods for the detection of phages}

Numbers of phages are generally determined by direct quantitative plaque assays, the principles of which were designed by Adams (1959). Molten agar is mixed with a suitable volume of the water under investigation and a culture of the host bacterium of choice at a temperature just above the solidification temperature of the agar. This mixture is poured on top of a bottom agar in a conventional $90 \mathrm{~mm}$ diameter petri dish. The plates are incubated and plaques scored the following day. In tests on waters containing high numbers of bacteria which may interfere with the host strain and the visibility of plaques, antibiotics such as nalidixic acid may be added to the agar medium and a resistant host strain is used. Technical details for these methods have been described elsewhere (ISO, 1995, 1998a,b; Grabow et al., 1993; Standard Methods, 1998).

However, the volume of test water per petri dish is generally limited to about $1 \mathrm{~m} \ell$. The quantitative detection of phages in numbers below the detection limit of direct plaque assays is, therefore, carried out by direct plaque assays using large petri dishes, or the recovery of phages from large volumes of water followed by conventional plaque assays on the concentrates. Small numbers of phages in large volumes of water may also be detected by qualitative enrichment procedures.

Molecular techniques for the detection of phages are beginning to appear on the scene (Rose et al. 1997; Puig et al.2000). However, these techniques still require optimisation and evaluation before they can be applied to a meaningful extent in routine water quality monitoring. The techniques are, therefore, not discussed in detail here.

This document outlines and summarises some of the latest approaches to techniques for the detection of phages most commonly used in water quality assessment as models/surrogates for human enteric viruses. Recommended techniques, to a large extent based on internationally-accepted principles and specifications, are summarised for somatic and F-RNA coliphages, and B. fragilis phages.

\section{Host strains}

A wide variety of host strains has been used for the detection of phages. Most of these host strains detect groups of phages. This applies in particular to somatic coliphages, where different host strains are susceptible to a different spectrum of phages. Counts of phages obtained for different hosts are, therefore, not comparable. Consequently, it is important to use standardised host strains which detect comparable groups of phages.

\section{Host strains for the detection of somatic coliphages}

Wild-type strains of E. coli are poor hosts for the detection of the wide variety of coliphages in waste waters (Hilton and Stotzky, 1973; Dhillon and Dhillon, 1974; Bell, 1976). Wild-type E. coli strains normally have a complete $\mathrm{O}$-antigen that masks the majority of phage receptor sites situated in the R-core of the cell wall 
lipopolysaccharide. In rough or semi-rough laboratory strains of $E$. coli these receptor sites are exposed and the bacteria are susceptible to a much wider spectrum of phages (Havelaar and Hogeboom, 1983). Laboratory strains of $E$. coli commonly used for the detection of coliphages include E. coli B (Kott, 1966b; Ayres, 1970; Dhillon et al., 1970; Bell, 1976; Gerba et al., 1978; Ignazitto et al., 1980; Nupen et al., 1980), E. coli C (Kenard and Valentine, 1974; Dhillon et al., 1976; Wentsel et al., 1983), or derivatives of E. coli K-12 strains like W3110 (Primrose et al., 1982). Defence mechanisms of wild-type $E$. coli strains against attack by phages also include nuclease enzymes which destroy nucleic acid recognised as foreign. These enzymes destroy the nucleic acid of many phages as soon as it is injected into the bacterial host and replication of the phage is prevented. Escherichia coli strain C (ATCC 13706), also known as WG4, is a mutant in which the genes which code for these nuclease enzymes have been deleted. This laboratory strain of $E$. coli is, therefore, susceptible to an even wider range of coliphages and is the host most commonly used for detecting somatic coliphages in water environments (ISO, 1998a, Grabow et al., 1998).

\section{Host strains for the detection of F-RNA coliphages}

As mentioned earlier, the receptor sites for male-specific coliphages are located on the fertility fimbriae of $E$. coli. These fimbriae are produced only by $E$. coli bacteria which carry the fertility $(\mathrm{F})$ plasmid which codes for the production of the fimbriae. Escherichia coli strain K12 typically carries the F-plasmid and is widely used for the detection of F-RNA (male-specific) phages (Dhillon et al., 1970; Kott et al., 1978; Glass and O'Brien, 1980; Primrose et al., 1982). Havelaar et al. (1984) applied genetic engineering to transfer the F plasmid from E. coli to a strain of Salmonella typhimurium. This strain then produced $E$. coli fimbriae and was suceptible to male-specific $E$. coli phages. The $S$. typhimurium strain was further modified by deleting its genes which code for pathogenicity in order to render it safe for routine work in water quality laboratories. This rather unique $S$. typhimurium strain is known as WG49 and is widely used as a host for the detection of male-specific coliphages (ISO, 1995; Grabow et al., 1998). The benefit of using an Styphimurium strain for the detection of malespecific coliphages is that it is not susceptible to the large numbers of somatic coliphages in water environments which tend to interfere with the detection of male-specific coliphages using E. coli hosts. Somatic phages which infect $S$ typhimurium are generally present in water environments in much lower numbers than somatic coliphages which implies that their interference with the detection of male-specific coliphages is generally negligible.

\section{Host strains for the detection of Bacteroides fragilis phages}

Tartera and Jofre (1987) found that phages which infect a certain strain of Bacteroides fragilis designated HSP40 (ATCC 51477) were not detected in the faeces of warm-blooded animals such as cows, pigs, rabbits, mice, poultry or quail, but only in human faeces. The specificity of $B$. fragilis HSP 40 phages for humans has been confirmed by Grabow et al. (1995). This feature implies that $B$. fragilis HSP40 phages may prove useful for distinguishing between faecal pollution of human and animal origin (Jagals et al., 1995).

However, in a survey of a variety of water environments, B. fragilis HSP40 phages have been found to outnumber cytopathogenic enteric viruses on average by only about five-fold, and enteric viruses were often detected in water samples which yielded negative results in tests for $B$. fragilis HSP40 phages (Grabow et al., 1993). More recent findings indicate that $B$. fragilis HSP40 phages are not detectable at all in water environments of some parts of the world. These findings distracted from initial interest in B. fragilis HSP40 phages as models/surrogates for enteric viruses in water quality assessment (Puig et al., 1999). The latest thinking favours a host which detects a wider spectrum of $B$. fragilis phages, including phages of both human and animal origin. Bacteroides fragilis strain RYC2056 has been recommended for this purpose (Puig et al., 1999; ISO, 1998b).

\section{Recovery methods}

Methods for the recovery of phages should ideally be rapid, inexpensive, simple, suitable for a wide range of waters including fresh-, sea- and estuarine waters, and they should yield a high efficiency of recovery. Techniques which have been applied and evaluated for this purpose include:

\section{Adsorption-elution methods}

A number of techniques have been described for the recovery of phages and viruses by approaches based on the filtration of test water through filter media to which the phages/viruses adsorb. The phages/viruses are afterwards released from the filter media into a small volume suitable for quantitative phage plaque assays. The principle involved is that viruses/phages carry a particular electrostatic charge which is predominantly negative at or near neutral $\mathrm{pH}$ levels. This charge on viruses/phages can be modified to predominantly positive by reducing the $\mathrm{pH}$ level to about 3.5 . At this $\mathrm{pH}$ level viruses/phages will adsorb to negatively charged filter media. The balance involved is rather delicate because the lower the $\mathrm{pH}$ the better the adsorption, but low $\mathrm{pH}$ levels inactivate phages/viruses, and the sensitivity of different phages and viruses to low $\mathrm{pH}$ levels differs. Hydrophobic interactions also seem to play a role in the adsorption process (Standard Methods, 1998). After adsorption, a small volume of a buffer at $\mathrm{pH} 9.5$ or higher is passed through the filter to reverse the charge on the viruses/phages to negative. This results in release of the viruses/phages and they can be detected by conventional methods (Gerba et al., 1978; Shields and Farrah, 1986). Alternatively filter media which carry a positive charge at neutral $\mathrm{pH}$ levels may be used, which implies that viruses/phages will adsorb at neutral $\mathrm{pH}$ levels. Viruses/ phages are also released from these filters by elution with high $\mathrm{pH}$ buffers. The most successful procedures on record include:

\section{Adsorption-elution methods using negatively-charged filter media}

\section{Electronegative adsorbent filters}

A variety of filter media have been used for the recovery of enteric viruses. Filters on which most information is available include cellulose nitrate and fibreglass acrylic resin membrane filters, both with $0.45 \mathrm{~mm}$ porosity (Standard Methods, 1998). The principles involved in the recovery of viruses/phages using all these filter media are basically the same and generally results do not differ significantly. Viruses have been recovered from seeded $20 \ell$ of drinking water or more at efficiencies of up to $90 \%$ (Goyal and Gerba, 1982; 1983). However, polio viruses were used in most efficiency tests which were carried out at extremely low adsorption $\mathrm{pH}$ levels and extremely high elution $\mathrm{pH}$ levels. Polio viruses are exceptionally resistant to these $\mathrm{pH}$ levels but no meaningful data are available for viruses which are less resistant.

The efficiency of recovery is affected by dissolved and colloidal 
organic matter which competes with viruses/phages for adsorption sites (Standard Methods, 1998). This may partly explain observations that an increase in the sample volume leads to a decrease in adsorption efficiency (Logan et al., 1980). Organic matter may also interfere with the elution of viruses from the filters. Another limitation is that suspended matter tends to clog the filters which limits the volume of the water that can be processed and prolongs the procedure. In order to avoid clogging, water is generally passed through prefilters to remove suspended material. Prefiltration has the disadvantage that viruses/phages adsorbed to suspended matter are removed from the water under investigation together with the suspended matter.

Di- and trivalent cations enhance the adsorption of viruses and phages to filters, possibly by altering the charge on the filter (Wallis et al., 1972), by altering the thickness of the layer of charges surrounding the surface of the filter (Valentine and Allison, 1959), or by forming salt bridges between the viruses and the filters (Kessick and Wagner, 1978). Farrah et al. (1981) found that magnesium sulphate promotes hydrophobic interactions between phage MS-2 and membrane filters, which is consistent with findings on adeno viruses (Fields and Metcalf, 1975). Cations such as aluminium chloride at a concentration of $0.001 \mathrm{M}$ are, therefore, added to test waters prior to filtration (Borrego et al., 1991). Cations also enhance the adsorption of phages to their host bacteria, and calcium and magnesium salts are routinely included in phage detection media (ISO, 1998a,b).

Although the recovery of polio and related viruses may be considered acceptable under certain conditions, evidence has been presented that the recovery of phages is poor, mainly because phages are inactivated by exposure to the $\mathrm{pH}$ extremes required for adsorption and elution (Seeley and Primrose, 1982). In addition, the procedure is expensive, labour intensive, cumbersome and time-consuming (Standard Methods, 1998).

\section{Glass powder}

Glass powder proved a useful medium for the adsorption-elution recovery of enteric viruses including entero, rota and hepatitis A viruses (Bosch et al., 1988, 1991; Gajardo et al., 1991). Glass powder carries a negative charge at neutral $\mathrm{pH}$ levels. In procedures for the recovery of viruses the $\mathrm{pH}$ of test water was reduced to 3.5 for adsorption of viruses to the glass powder. A pH 11.5 buffer was used to elute viruses from the glass powder (Vilagines et al., 1993). Although no meaningful data are on record, the technique would not appear suitable for the recovery of phages because most phages would fail to survive the $\mathrm{pH}$ extremes involved (Seeley and Primrose, 1982). In addition, the procedure has the same shortcomings and limitations described for other adsorption-elution procedures.

\section{Adsorption-elution methods using positively-charged filter media}

\section{Electropositive membrane filters}

Shortcomings of negatively-charged filter media led to the development of membranes which carry a positive surface charge at neutral $\mathrm{pH}$ levels. These filters eliminate the need for $\mathrm{pH}$ reduction of test water because the negatively-charged viruses and phages adsorb to the filters at or near neutral pH levels (Sobsey and Glass, 1980). A variety of membranes and filter systems is available, among the well-known ones are CUNO 1-MDS Virosorb and CUNO Zeta Plus 50-S or 60-S filters. Application of these and related positivelycharged filters in procedures with a wide variety of modifications and variations were used to recover enteric viruses and phages (Primrose and Day, 1977; Seeley et al., 1979; Logan et al., 1980;
Singh and Gerba, 1983; Goyal et al., 1987; Sinton et al, 1996). Goyal et al. (1980) used positively-charged Zeta Plus filters to recover coliphages MS-2, X-174, T2 and T4 from 17 litre volumes of tap water, sewage and lake water. Efficiencies of recovery ranged between $34 \%$ and $100 \%$.

Although positively-charged adsorption-elution systems seem to generally yield recoveries of phages superior to those of negatively-charged filter systems, they still have shortcomings. The efficiencies of recovery reported by different laboratories for the same and different phages are highly variable (Goyal et al., 1980; Singh and Gerba, 1983; Rose et al., 1984; Grabow et al., 1993), the procedures remain relatively expensive, labour-intensive and timeconsuming. Asbestos-containing and diatomaceous earth filters have slow flow rates which prohibit the recovery of phages from large volumes of water, and organic compounds significantly affect virus adsorption (Sobsey and Glass, 1980; Rose et al., 1984; Preston et al., 1988; Borrego et al., 1991).

Sobsey et al. (1990) developed a relatively simple, inexpensive and practical procedure for the recovery and detection of F-RNA coliphages using mixed cellulose nitrate and acetate membrane filters with a diameter of $47 \mathrm{~mm}$ and a pore size of $0.45 \mathrm{~mm}$. Optimum adsorption of phages was at $\mathrm{pH}$ levels ranging from 6 to 9, which implied that no $\mathrm{pH}$ adjustment was required for most raw and treated water supplies. Magnesium chloride at a final concentration of $0.05 \mathrm{M}$ was added to test samples to facilitate phage adsorption. After filtration the membranes were placed face downward onto an agar medium containing host bacteria and incubated overnight. Phages present on the membranes infected the host bacteria and produced plaques. Numbers of phages present in test samples could, therefore, be counted directly. Tetrazolium violet was added to the phage growth medium to enhance the visibility of plaques. The method proved to be suitable for analysis of 100 to $2000 \mathrm{~m} \ell$ volumes of tap water and 100 to $300 \mathrm{~m} \ell$ volumes of surface water. The efficiency of recovery of seeded F-RNA phages from $100 \mathrm{~m} \ell$ samples of tap water was $49 \%$, which gradually decreased with increasing test volume to $12 \%$ for $2000 \mathrm{~m} \ell$. The efficiency of recovery from $100 \mathrm{~m} \ell$ and $300 \mathrm{~m} \ell$ surface water was $34 \%$ and $18 \%$, respectively. Although the procedure has attractive features, it should be weighed up against direct plaque assays on $100 \mathrm{~m} \ell$ samples, and presence-absence tests on $500 \mathrm{~m} \ell$ samples, both of which have theoretical efficiencies of $100 \%$ (Grabow et al., 1998; Hayward, 1999; Uys, 1999). Test volumes of the latter assays can be increased without loss of efficiency, as will be discussed later.

\section{Charge modified glass powder}

The surface charge of glass powder can be changed from negative to positive by treatment with polyethylenimine (Gajardo et al., 1991). Bosch et al. (1991) recovered hepatitis A virus from 20-litre volumes of various waters at efficiencies ranging from $60 \%$ to $100 \%$ using this charge modified glass powder. An assessment of the method for the recovery of somatic coliphage V1 and Bacteroides fragilis phage B40-8 from $10 \ell$ volumes of tap water indicated that on average about $97 \%$ of the phages adsorbed to the glass powder. However, release from the glass powder by means of the $\mathrm{pH} 9$ sodium chloride-beef extract elution buffer used for hepatitis A virus was poor, and average efficiencies of recovery were $20 \%$ for $\mathrm{V} 1$ and $18 \%$ for B40-8 (Grabow et al., 1993). In addition, it appeared that the glass powder lost its positive charge as the volume of water passed through the column was increased. The procedure also displayed other shortcomings common to adsorption-elution procedures discussed earlier. 


\section{Glass wool}

Oiled sodocalcic glass wool marketed under the trade name "Rantigny 725" by Isover-Orgel, Saint Gobain, France, has surface electrostatic and hydrophobic properties which facilitate the adsorption of a variety of enteric viruses at $\mathrm{pH}$ levels near neutral (Sarrette et al., 1977; Vilaginès et al., 1993). Columns of this glass wool proved suitable for the routine recovery of enteric viruses from large volumes of water at efficiencies of $80 \%$ to $95 \%$ depending on the quality of the water (Vilaginès et al., 1997). Recovery of viruses from the glass wool is accomplished by elution with a relatively mild $\mathrm{pH} 9.5$ beef extract-glycine buffer. In studies on the recovery of phages by this procedure, F-RNA coliphage MS2 was used as a model (Grabow et al., 1998). The results revealed that $72 \%$ (range 64 to $83 \%$ ) of seeded phage in $5 \ell$ samples of dechlorinated tap water failed to adsorb. The eventual average efficiency of recovery was $1.1 \%$ (range 0.3 to $1.8 \%$ ) which implies that elution of the $28 \%$ of phages which did adsorb to the glass wool, was poor. Phages were enumerated by plaque assays, which implies that inactivation of phages by the elution process may at least partly account for the low efficiency of recovery of viable phages. These findings suggest that the glass wool procedure used for the recovery of enteric viruses is not suitable for the recovery of phages.

\section{Ultrafiltration}

Ultrafiltration is based on the filtration of water through membranes of polysulphonate or related material with a nominal molecular weight cut-off limit of about 10000 . Particles with a diameter of $0.02 \mathrm{~mm}$ or more fail to pass through these membranes. Water molecules pass through the pores of these membranes but viruses and phages are too large to do so. It is, therefore, a process in which viruses are physically retained and adsorption or elution play no fundamental role (Strohmaier, 1967; Sweet et al., 1974). Filter systems include sheet membranes against which the water is kept in motion by means of a recirculating pump or stirring apparatus to enhance the filtration rate and to avoid clogging (Berman et al., 1980; Logan et al., 1980; Nupen et al., 1980; Jansons and Buccens, 1986; Grabow et al., 1993). Other systems which are commercially available consist of units in which filtration is enhanced by tangential flow through hollow fibres with a large total filtration surface area.

As may theoretically be expected, ultrafiltration has a high efficiency of recovery. This has been confirmed in many studies. Efficiencies of recovery approaching $100 \%$ have been reported for various commercial filter devices with different diameters of flat sheet ultrafiltration membranes (Berman et al., 1980; Nupen et al., 1980; Divizia et al., 1989; Grabow et al., 1993,1998). Turbidity of water under investigation tends to affect the efficiency of recovery because viruses adsorb to particulate matter and after filtration there are invariably losses when viruses are separated from the rest of the retentate. The efficiency of a hollow fibre unit was found to be less than that of flat sheet membranes (Grabow et al., 1993).

Advantages of ultrafiltration include high efficiencies of recovery and viruses/phages are not exposed to $\mathrm{pH}$ extremes or other unfavourable conditions which may affect their viability. Adsorption of viruses and phages to the membranes is minimal, and this can be reduced by pretreatment of the membranes with beef extract which seems to block potential adsorption sites for viruses and phages (Divizia et al., 1989). The most important disadvantage is that the membranes clog rapidly which implies that the volumes of water that can be processed are restricted. However, viruses and phages can efficiently be recovered from low turbidity tap water in volumes up to $10 \ell$ using large diameter flat membranes (Nupen et al., 1980). Hollow fibre units are capable of processing substantially larger volumes, but the volume of retentate is also larger and secondary concentration may be required, all of which reduces the efficiency of recovery (Grabow et al., 1993). A major disadvantage is the cost of the capital equipment and the membranes.

\section{Flocculation}

Relatively successful techniques are on record for the recovery of enteric viruses from water by adsorption of viruses to flocculants such as aluminium hydroxide (Standard Methods, 1998). The process probably involves both electrostatic interactions between the negatively-charged virus surface and the positively charged aluminium hydroxide surfaces and coordination of the virus surface by hydroxo-aluminium complexes. Flocks are generally recovered by centrifugation or filtration. The flocks are then disintegrated by vigorous shaking and the viruses recovered by centrifugation (Standard Methods, 1998). The procedure is suitable for the recovery of viruses from only several litres of water, and the efficiency of recovery is relatively low. Although little information is available on the suitability of the method for the recovery of phages, it may theoretical be expected to be as suitable for phages as for enteric viruses. This has been confirmed in tests using ammonium sulphate supplemented with beef extract for flocculation which yielded average efficiencies of recovery of $85 \%$ for phages MS2, X174 and T3 (Shields and Farrah,1986). Modifications of the procedure include magnetic organic flocculation, in which casein flocks are formed in the presence of magnetite for subsequent collection of the flocks by means of a magnet. The recovery of coliphages from waste- and lake water by means of this procedure has been described (Bitton et al., 1981; Kennedy et al., 1985).

\section{Hydro-extraction}

This procedure is based on placing a water sample into a cellulose dialysis bag which is exposed to hygroscopic material such as polyethylene glycol (PEG). The PEG extracts water and microsolutes through the semipermeable membrane while viruses and other macrosolutes remain inside. The procedure is recommended as an option for the recovery of viruses from small volumes of water, not more than a few hundred millilitres (Standard Methods, 1998). No meaningful information is available on the suitability of the method for the recovery of phages, but theoretically it may be as suitable for phages as for viruses. This seems to have been confirmed by Padan et al. (1967) who used the method to recover cyanophages from ponds.

\section{Secondary concentration methods}

The concentrate of some recovery techniques, notably adsorptionelution procedures, may still have a volume of 100-200 m $\ell$ or more. In these cases secondary concentration procedures are generally applied to reduce the volume to $10 \mathrm{~m} \ell$ or less (Standard Methods, 1998). Secondary concentration procedures used for viruses include adsorption-elution using smaller filters (Farrah and Bitton, 1979; Shields et al., 1985), hydro-extraction (Farrah et al., 1977), ultrafiltration (Selna and Miele, 1977; Divizia et al., 1989), and inorganic (Wallis et al., 1972; Farrah et al., 1976) or organic (Katzenelson et al., 1976) flocculation. The latter authors developed a procedure which is widely used for the secondary recovery of viruses. It is based on the elution of viruses from adsorption-elution filters using buffers which contain beef extract. After elution the $\mathrm{pH}$ of the buffer is reduced to 3,5 which triggers flocculation of the 


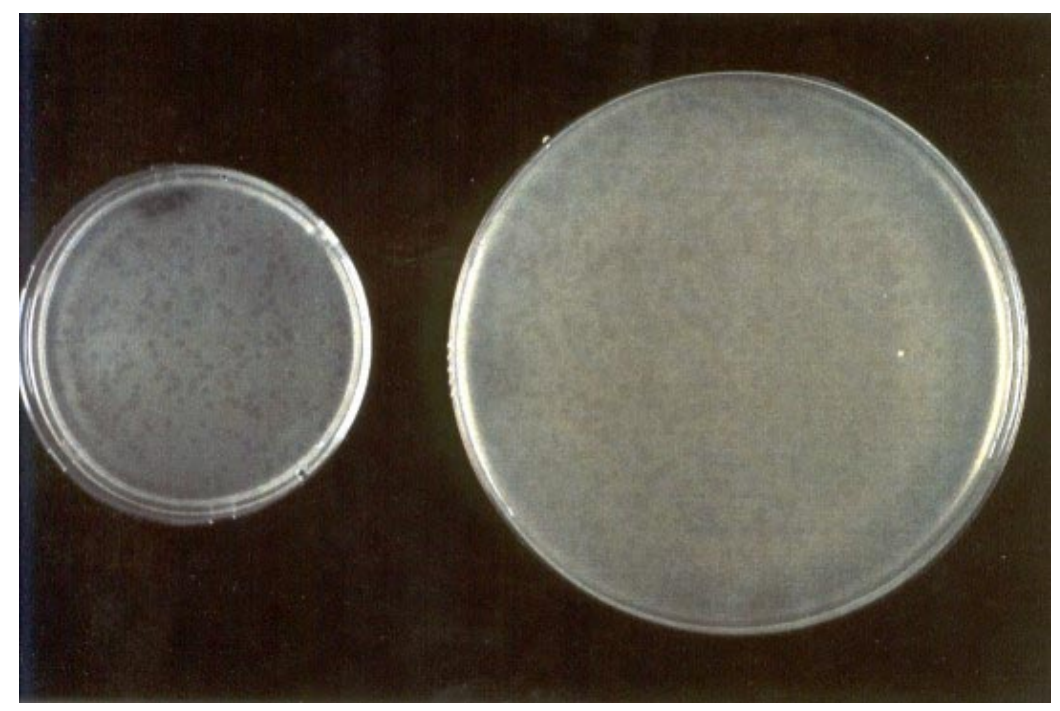

Figure 3

Plaques produced by F-RNA phages in direct plaque assays on a $1 \mathrm{~m}$ water sample in a small petri dish (diameter $90 \mathrm{~mm}$ ) (left) and on a $100 \mathrm{~m}$ sample using large petri dishes (diameter $140 \mathrm{~mm}$ ) (right)

beef extract. The flocks with adsorbed viruses are then recovered and processed further as described earlier. However, according to several reports the technique is not well-suited for phages (Hurst et al., 1989; Payment et al., 1989). This may largely be due to inactivation of phages by exposure to the low $\mathrm{pH}$ level (Dahling and Wright, 1986; Jothikumar et al., 1990). The flocculation procedure using ammonium sulphate yielded superior results (Shields and Farrah, 1986).

\section{Direct plaque assays on large volumes}

Direct plaque assays on $100 \mathrm{~m} \ell$ volumes of water have been described (Grabow and Coubrough, 1986). These assays were based on mixing test water samples of $100 \mathrm{~m} \ell$ with concentrated agar media just above the agar solidification temperature. Host culture was then added, the mixture poured into $140 \mathrm{~mm}$ diameter petri dishes, and after solidification the plates were incubated for counting plaques the following day. This procedure has been modified by pouring the mixture in equal volumes on top of a bottom agar layer in ten large petri dishes (Grabow et al., 1998; Uys, 1999; Hayward, 1999) (Fig. 3). This double agar layer procedure resembles double agar-layer plaque assays commonly used on smaller volumes of water. The double agar layer procedure yielded substantially higher counts for somatic coliphages, F-RNA coliphages and $B$. fragilis phages in seeding experiments as well as comparative tests on a variety of raw and treated water supplies (Grabow et al., 1998, Uys, 1999). The principle of double agar layer plaque assays on large volumes of water using large petri dishes for F-RNA phages is also recommended in ISO (1995).

Evidence has been presented that somatic coliphages, F-RNA coliphages and $B$. fragilis phages can be detected in waters which yield negative results by conventional plaque assays using small petri dishes and small volumes of water such as 1 to $10 \mathrm{~m} \ell$ (Grabow et al., 1998; Uys, 1999). The procedure has the advantage of direct plaque assays, which eliminates losses of phages invariable incurred by recovery techniques (Sobsey et al., 1990). Multiples of the test can be carried out to analyse larger volumes of water. The method proved to be ideally suited for the accurate counting of phages in $100 \mathrm{~m} \ell$ volumes of treated drinking water supplies, and relatively unpolluted raw water sources. The procedure is simple and can be carried out in conventional water quality laboratories. The large petri dishes are more expensive than the conventional small (90 $\mathrm{mm}$ diameter) petri dishes, and a substantial quantity of agar medium is required. However, the procedure is less expensive, more user-friendly and more accurate than comparable options such as recovery of phages by adsorption-elution procedures or ultrafiltration (Grabow et al., 1998).

\section{Qualitative presence-absence enrichment tests}

This approach has probably first been described by Guelin (1948). It is based on adding nutrients and a host culture of choice to the sample of water under investigation. The mixture is then incubated and any phage present will infect the host bacteria and replicate. After overnight incubation phages present in the sample (which may be a single phage) have replicated to large numbers which are readily detectable by plaque assays or spot tests (Kott, 1966a; Hilton and Stotsky, 1973; Grabow et al., 1993, 1998) and even electron microscopy (Ackermann and Nguyen, 1983). Selectivity for particular phages may be enhanced by creating conditions which favour the replication of their hosts. For instance, antibiotics may be added to the reaction mixture and hosts resistant to the antibiotics may be used. The selective replication of $B$. fragilis phages is promoted by the incubation of reaction mixtures under strict anaerobic conditions. Inherently the system promotes sensitivity by allowing recovery of injured phage particles and the adaptation of phages to host bacteria, which is not possible under the comparably hostile conditions in direct plaque assays, and even less so in many recovery techniques. The principle can be applied for the highly accurate detection of phages in small volumes of water such as $1 \mathrm{~m} \ell$ (Kott, 1966a; ISO, 1998), or in large volumes of water such as $100 \mathrm{~m} \ell, 500 \mathrm{~m} \ell$ or even $1000 \mathrm{~m} \ell$ (Grabow et al., 1993, 1998). Kott (1966a) applied the principle in a most probable number procedure for phages.

The procedure proved ideally suited for the highly sensitive monitoring of the presence of phages in treated drinking water supplies (Grabow et al., 1998; Hayward, 1999). In a series of comparative tests on different volumes of water, positive results were rarely obtained for larger volumes of water which yielded negative results for $500 \mathrm{~m} \ell$ samples, indicating that $500 \mathrm{~m} \ell$ is a 
convenient and practical volume for routine monitoring of drinking water supplies.

The procedure does, of course, yield qualitative results only, and gives no indication of the number of phages present in the original sample. However, quality guidelines for drinking water are largely based on the qualitative absence of indicators and pathogens from recommended volumes of water (WHO, 1993, 1996, 1997).

The technique is restricted to particular phages of choice and is not suitable for the detection of a wide spectrum of phages. For certain purposes this is a disadvantage (Seeley and Primrose, 1982; Goyal et al., 1987). However, for purposes of water quality monitoring this is a distinctive advantage, because water quality guidelines specify particular phages and not the total phage population. In addition, the specificity for particular phages increases sensitivity and reliability because interference and overgrowth by other phages and their hosts is restricted. The same benefits apply to the application of selected phages as models/ surrogates for enteric viruses in comparative studies on survival and behaviour.

The tests are simple and can be carried out in conventional microbiology laboratories. Their extreme sensitivity has the disadvantage of being vulnerable to contamination with phages. In the performance of the test, the utmost caution is essential to avoid contamination of the water sample or the reaction mixture with phages. A substantial amount of nutrients is required. However, compared to the cost of phage recovery procedures described earlier, the procedure is very inexpensive. If other benefits such as sensitivity and simplicity, and time and labour, are taken into consideration, it stands out as a most valuable tool for water quality assessment.

\section{Rapid detection methods}

Techniques have been described for shortening the time required to obtain results (Armon and Kott, 1993; Ijzerman et al., 1994). An analysis of these procedures revealed that they have merit for certain purposes. However, for general purposes of water quality assessment and the application of phages as models/surrogates for human viruses, they proved complicated, labour-intensive and expensive, while the extent to which optimum results were available sooner than conventional plaque assays or presence-absence tests was not meaningful (Grabow et al., 1998).

The addition of dyes such as 2,3,5-triphenyl tetrazolium hydrochloride (Standard Methods, 1998) and tetrazolium violet (Sobsey et al., 1990) to plaque assay media may under circumstances enhance the visibility of plaques (Grabow et al., 1998). However, for general purposes this proved hardly worth the while (Grabow et al., 1998). Claims that tetrazolium salts may inhibit plaque formation by phages belonging to the families Podoviridae and Siphoviridae (Hurst et al., 1994) could not be confirmed (Grabow et al., 1998).

\section{Conclusions}

The properties and features which render phages attractive models or surrogates for assessment of the incidence and behaviour of viruses in polluted water environments have been reviewed. Reference has been made to studies worldwide which support the value of phages as practical and economic tools for monitoring the safety of water supplies and the efficiency of water treatment and disinfection processes with regard to human and animal viruses.

Shortcomings in methods for the detection of phages in water and related environments have been outlined. The wide variety of techniques applied in the past, notably with regard to host bacteria employed for the detection of various phages, have unfortunately produced results which tend to be confusing and often contradictory. However, research and evaluation of many options have generated information for the development of practical and reliable techniques. This information is now being used by international bodies such as the International Organisation for Standardisation and the World Health Organisation to formulate techniques which can be applied universally to obtain reliable and comparable results.

Despite sound progress, there is much room for further development. Even though techniques for the detection of phages are basically simple and inexpensive, technology for application in practice tends to lag behind that of human and animal viruses which requires more complicated and expensive detection techniques in various ways. This is reflected by reports on the detection of viruses in treated water supplies which yield negative results by conventional tests for phages. For instance, molecular techniques comparable to those used for the detection of enteric viruses are only beginning to surface in procedures for the detection of phages. Likewise, techniques for the recovery of phages from large volumes of water are also behind those of viruses.

In terms of data analysed in this update the following techniques based on internationally accepted principles and procedures are recommended for routine monitoring and quality assessment purposes:

The phages most commonly used as models or surrogates for enteric viruses are somatic coliphages detected by Escherichia coli strain C, F-RNA coliphages detected by Salmonella typhimurium strain WG49, and Bacteroides fragilis phages detected by $B$. fragilis strain RYC2056. The methods of choice for general purposes are:

- Direct plaque assays with double agar layers in small petri dishes ( $90 \mathrm{~mm}$ diameter) and $1 \mathrm{~m} \ell$ of test water per plate (Grabow et al., 1998; ISO 1998a, 1998b).

Ten plates can be prepared to obtain counts per $10 \mathrm{~m} \ell$. This proved that the method of choice for waters which contain high numbers of phages such as sewage, abattoir effluents, stormwater run-off, treated waste waters and heavily-polluted environmental waters.

- Direct plaque assays with double agar layers in large petri dishes (140 mm diameter) and $10 \mathrm{~m} \ell$ of test water per plate (ISO, 1995; Grabow et al., 1998).

Ten plates can be prepared to obtain counts per $100 \mathrm{~m} \ell$. This proved the method of choice for testing relatively unpolluted water sources, waters used for recreational purposes, and treated drinking water supplies. Alternatives would include recovery of phages by ultrafiltation or adsorption-elution techniques.

- Qualitative presence-absence tests on $500 \mathrm{~m} \ell$ samples (Grabow et al., 1998; ISO, 1998a).

The method of choice for monitoring treated drinking water supplies. Alternatives would include recovery of phages by ultrafiltation or adsorption-elution techniques.

\section{Acknowledgements}

Thanks are due to the Water Research Commission for financial support and to many colleagues worldwide for advice and assistance. 


\section{References}

ABELES AL, SNYDER KM and CHATTORAJ DK (1984) P1 plasmid replication: Replicon structure. J. Mol. Biol. 17 307-324.

ACKERMANN HW and NGUYEN TM (1983) Sewage coliphages studied by electron microscopy. Appl. Environ. Microbiol. 45 10491059.

ACKERMANN HW (1969) Bacteriophages proprietes et premieres etapes d'une classification. Path-Biol. 17 1003-1024.

ADAMS MH (1953a) Criteria for a biological classification of bacterial viruses. Апnи. N. Y. Acad. Sci. 56 442-459.

ADAMS MH(1953b) Bacteriophages. New York: Interscience Publishers, Inc.

ADAMS MH (1959) Bacteriophages. Interscience, New York.

ARAUJO R, LASOBRAS J, PUIG A, LUCENA F and JOFRE J (1997) Abundance of bacteriophages of enteric bacteria in different freshwater environments. Water Sci. Technol. 35 125-128.

ARMON R and KOTT Y (1993) A simple, rapid and sensitive presence/ absence detection test for bacteriophage in drinking water. J. Appl. Bact. 74 490-496.

ATKINS JF, STEITZ JA, ANDERSON CW and MODEL P (1979) Binding of mammalian ribosomes to MS2 phage RNA reveals an overlapping gene encoding a lysis function. Cell 18 247-256.

AYRES PA (1970) Coliphages in sewage and the marine environment. In SkinnerFA and J M Shewan JM (eds.) Aquatic Microbiology. Academic Press, London. 275-298.

BEEKWILDER J, NIEUWENHUIZEN R, HAVELAAR AH and VAN DUIN J (1996) An oligonucleotide hybridization assay for the identification and enumeration of F-specific RNA phages in surface water. J. Appl. Bact. 80 179-186.

BELL RG (1976) The limitation of the ratio of fecal coliform to total coliphage as a water pollution index. Water Res. 10 745-748.

BEREMAND MN and BLUMENTHAL T (1979) Overlapping genes in RNA phage: A new protein implicated in lysis. Cell 18 257-266.

BERGH O, BORSHEIM KY, BRATBAK G and HELDAL M(1989) High abundance of viruses found in aqautic environments. Nature $\mathbf{3 4 0}$ 467-469.

BERMAN D, ROHR M and SAFFERMAN RS (1980) Concentration of poliovirus in water by molecular filtration. Appl. Environ. Microbiol. 40 426-428.

BERRY SA and NOTONBG (1976) Survival of bacteriophages in seawater Water. Res. 10 323-327.

BIRGE EA (1981) Bacterial and Bacteriophage Genetics. Springer Verlag, New York.

BITTON G, CHANG LT, FARRAH SR and CLIFFORD K (1981) Recovery of coliphages from wastewater effluent and lake water by the magnetite-organic flocculation method. Appl. Environ. Microbiol. 41 93-96.

BITTON G (1987) Fate of bacteriophages in water and wastewater treatment plants. In: Goyal SM, Gerba CP and Bitton G (eds.) Phage Ecology. Whiley, New York. 181-195.

BIXBY RL and O'BRIEN DJ (1979) Influence of fulvic acid on bacteriophage adsorption and complexation in soil. Appl. Environ. Microbiol. 38 840-845.

BOOTH SJ, VAN TASSEL RL, JOHNSON JL and WILKENS TD (1979) Bacteriophages of Bacteroides. Rev. Infect. Dis. 1 325-334.

BORREGOJJ, ARRABALF, DE VICENTE A, GOMEZLF and ROMERO $P$ (1983) Study of microbial inactivation in the marine environment J. Water Pollut. Control Fed. 55 297-302.

BORREGO JJ, MORINIGO MA, DE VICENTE A, CORNAX R and ROMERO P (1987) Coliphages as an indicator of faecal pollution in water, its relationship with indicator and pathogenic micro-organisms. Water Res. 21 1473-1480.

BORREGOJJ,CORNAXR, MORINIGOMA, MARTINEZ-MANZARES E and ROMERO P (1990) Coliphages as an indicator of faeca pollution in water. Their survival and productive infectivity in natural aquatic environment. Water Res. 24 111-116.

BORREGOJJ,CORNAXR, PRESTONDR,FARRAHSR, McELHANEY B and BITTON G (1991) Development and application of new positively charged filters for recovery of bacteriophages from water. Appl. Environ. Microbiol. 57 1218-1222.
BOSCH A, GAJARDO R, ABAD FX, DIEZ JM and JOFRE J (1991) Concentration of hepatitis A virus in environmental samples. Water Sci. Technol. 24 229-234.

BOSCH A, PINTO RM, BLANCH AR and JOFRE J (1988) Detection of human rotavirus in sewage through two concentration procedures. Water Res. 22 343-348.

BROCK TD and MADIGAN MT (1988) Biology of Microorganisms (5th edn.) Prentice Hall International, Inc.

BULMER M (1989) Codon usage and secondary structure of MS-2 phage RNA. Nucl. Acids Res. 17 1839-1843.

BURGE WD, COLACICCO D and CRAMER WN (1981) Criteria for achieving pathogen destruction during composting. J. Water Pollut. Control Fed. 53 1683-1690.

COETZEE OJ (1962) Bakteriophagen als Indikator fakaler Wasserverunreinigung. Gesundheits-Ing. 12 371-372.

DAHLING DR and WRIGHT BA (1986) Recovery of viruses from water by a modified flocculation procedure for second-step concentration. Appl. Environ. Microbiol. 51 1326-1331.

DAVIS BD, DULBECCO R, EISEN HN and GINSBERG HS (1990) Microbiology (4th edn.) J B Lippincott Company, Philadelphia.

DEBARTOLOMEIS J and CABELLI VJ (1991) Evaluation of an Escherichia coli host strain for enumeration of $\mathrm{F}$ male-specific bacteriophages. Appl. Eviron. Microbiol. 57 1301-1305.

DEETZ TR, SMITH ER, GOYAL SM, GERBA CP, VALLET JV, TSAI HL, DUPONT HL and HESWICK BH (1984) Occurence of rota and enteroviruses in drinking and environmental waters in a developing nation. Water Res. 18 572-577.

DE MESQUITA MMF (1988) Bacterial and Bacteriophage Investigations Using the Mussel Mytilus edulis. Ph.D. thesis, Univ. of Newcastle upon Tyne. $244 \mathrm{pp}$

DHILLON EKS and DHILLON TS (1974) Synthesis of indicator strains and density of ribonucleic acid-containing coliphages in sewage. Appl. Microbiol. 27 640-647.

DHILLON TS, DHILLON EKS, CHAU HC, LI WK and TSANG HC (1976) Studies on bacteriophage distribution: Virulent and temperate bacteriophage content of mammalian feces. Appl. Environ. Microbiol. 32 68-74.

DHILLON TS, CHAN YS, SUN SM, and CHAU WS (1970) Distribution of coliphages in Hong Kong sewage. Appl. Microbiol. 20 187-191.

DIVIZIA M, SANTI AL and PANA A (1989) Ultrafiltration: An efficient second step for hepatitis A virus and poliovirus concentration. J. Virol. Methods 23 55-62.

EPA (1986) Report of Task Force on Guide Standard and Protocol for Testing Microbiological Water Purifiers. US Environmental Protection Agency, Cincinnati. 1-29.

EWERT DL and PAYNTER MJB (1980) Enumeration of bacteriophages and host bacteria in sewage and the activated sludge treatment process. Appl. Environ. Microbiol. 39 576-583.

FARRAH SR, GERBA CP, WALLIS C and MELNICK JL (1976) Concentration of viruses from large volumes of tap water using pleated membrane filters. Appl. Environ. Microbiol. 31 221-226.

FARRAH SR, GOYAL SM, GERBA CP, WALLIS C and MELNICK JL (1977) Concentration of enteroviruses from estuarine water. Appl. Environ. Microbiol. 33 1192-1196.

FARRAH SR and BITTON G(1979) Low molecular weight substitutes for beef extract as eluants for poliovirus adsorbed to membrane filters. Can. J. Microbiol. 25 1045-1051.

FARRAH SR, SHAH DO and INGRAM LO (1981) Effects of chaotropic and antichaotropic agents on elution of poliovirus adsorbed to membrane filters. Proc. Natl. Acad. Sci. USA 78 1229-1232.

FIELDS HA and METCALFTG (1975) Concentration of adenovirus from seawater. Water Res. 9 357-364.

FREIFELDER D (1987) Molecular Biology (2nd edn.) Jones and Bartlett Publishers, Inc. Boston, Portola Valley. 551-593.

FROST JA, CHEASTY T, THOMAS A and ROWE B (1993) Phage typing of Vero cytotoxin-producing Escherichia coli $\mathrm{O} 157$ isolated in the United Kingdom: 1989-91. Epidemiol. Infect. 110 469-475.

FURUSE K, OSAWA S, KAWASHIRO J, TANAKA R, OZAWA Z, SAWAMURA S, YANAGAWA Y, NAGAO T and WATANABE I (1983) Bacteriophage distribution in human faeces: continuous survey of healthy subjects and patients with internal and leukemic diseases. J. Gen. Virol. 64 2039-2043. 
FURUSE K, ADOI T, SHIBA T, SAKURAI T, MIYAKE T and WATANABE I (1973) Isolation and grouping of RNA phages. IV. A survey in Japan. J. Keio Med. Soc. 50 363-376.

GAJARDO R, DIEZ JM, JOFRE J and BOSCH A (1991) Adsorptionelution with negatively and positively-charged glass powder for the concentration of hepatitis A virus from water. J. Virol. Methods $\mathbf{3 1}$ 345-352.

GELDREICH EE (1978) Bacterial populations and indicator concepts in faeces, sewage, stormwater and solid wastes. In: Berg G(ed.) Indicators of Viruses in Water and Food. Ann Arbor Science Publishers, Inc., Ann Arbor, Mich. 51-97.

GERBA CP, FARRAH SR, GOYAL SM, WALLIS C, and MELNICK JL (1978) Concentration of enteroviruses from large volumes of tapwater, treated sewage, and seawater. Appl. Environ. Microbiol. 35 540-548.

GERBA CP, STAGG CH and ABADIE MG (1978) Characterization of sewage solid-associated viruses and behavior in natural waters. Water Res. 12 805-812.

GERBA C P (1987) Phage as indicators of faecal pollution. In: Goyal SM, Gerba CP and Bitton G (eds.) Phage Ecology. Whiley, New York. 197209.

GLASS JS and O'BRIENRT (1980) Enterovirus and coliphage inactivation during activated sludge treatment. Water Res. 14 877-882.

GOYAL SM (1980) Indicators of viruses. In: Berg G (ed.) Viral Pollution of the Environment. CRC Press, Boca Raton, Florida.

GOYAL SM and GERBA CP (1982) Concentration of coliphages from water by membrane filters. In: Methods in Environmental Virology. Marcel Dekker, New York. 59-116.

GOYAL SM and GERBA CP (1983) Viradel method for detection of rotavirus from seawater. J. Virol. Methods 7 279-285.

GOYAL SM, GERBA CP and BITTON G (1987) Phage Ecology. John Wiley and Sons, New York. 321 pp.

GOYAL SM, ZERDA KS and GERBA CP (1980) Concentration of coliphages from large volumes of water and wastewater. Appl. Environ. Microbiol. 39 85-91.

GRABOW WOK (1986) Indicator systems for assessment of the virological safety of treated drinking water. Water Sci. Technol. 18 159-165.

GRABOW WOK (1990) Microbiology of drinking water treatment: reclaimed wastewater. In: McFeters GA (ed.) Drinking Water Microbiology - Progress and Recent Developments. Springer Verlag, New York. 185-203.

GRABOW WOK (1996) Waterborne diseases: Update on water quality assessment and control. Water SA 22 193-202.

GRABOW WOK, BOTMA KL, DE VILLIERS JC, CLAY CG and ERASMUS B (1999a) Assessment of cell culture and polymerase chain reaction procedures for the detection of polioviruses in wastewater. Bull. World Health Org. 77 973-980.

GRABOW WOK, BURGER JS and NUPEN EM (1980) Evaluation of acid-fast bacteria, Candida albicans, enteric viruses and conventional indicators for monitoring wastewater reclamation systems. Prog. Water Technol. 12 803-817.

GRABOW WOK, CLAY CG, DHALIWAL W, VREY MA and MÜLLER EE (1999b) Elimination of viruses, phages, bacteria and Cryptosporidium by a new generation Aquaguard point-of-use water treatment unit. Zentbl. Hyg. Umweltmed. 202 399-410.

GRABOW WOK and COUBROUGH P (1986) A practical direct plaque assay for coliphages in $100 \mathrm{~m} \ell$ samples of drinking water. Appl. Environ. Microbiol. 52 430-433.

GRABOW WOK, COUBROUGH P, NUPEN EM and BATEMAN BW (1984) Evaluation of coliphages as indicators of the virological quality of sewage-polluted water. Water SA 10 7-14.

GRABOW WOK, GAUSS-MÜLLER V, PROZESKY OW and DEINHARDT F (1983) Inactivation of Hepatitis A virus and indicator organisms in water by free chlorine residuals. Appl. Environ. Microbiol. 46 619-624.

GRABOW WOK, HOLTZHAUSEN CS and DE VILLIERS JC (1993) Research on Bacteriophages as Indicators of Water Quality. WRC Report No 321/1/93. Water Research Commission, Pretoria. 147 pp.

GRABOW WOK, IDEMA GK, COUBROUGH P and BATEMAN BW (1989) Selection of indicator systems for human viruses in polluted seawater and shellfish. Water Sci. Tecnol. 21 111-117.
GRABOW WOK, NEUBRECH TE, HOLTZHAUSEN CS and JOFRE J (1995) Bacteroides fragilis and Escherichia coli bacteriophages: Excretion by humans and animals. Water Sci. Technol. 31 223-230.

GRABOW WOK, TAYLOR MB, CLAY CG and DE VILLIERS JC (2000) Molecular detection of viruses in drinking water: Implications for safety and disinfection. Proc. 2nd Conf. of the Int. Life Sciences Inst.: The Safety of Water Disinfection: Balancing Chem. and Microb. Risks. Radisson Deauville Resort, Miami Beach, Florida, USA, 15-17 November.

GRABOW WOK, VAN DER VEEN A and DE VILLIERS JC (1999c) Marine Pollution: Pathogenic Micro-organisms in Shellfish. WRC Report No 411/1/99. Water Research Commission, Pretoria. 179 pp.

GRABOW WOK, VREY A, UYS M and DE VILLIERS JC (1998) Evaluation of the Application of Bacteriophages as Indicators of Water Quality. WRC Report No 540/1/98. Water Research Commission, Pretoria. $55 \mathrm{pp}$.

GREEN J, BRICE K, CONNER C and MUTESI R (2000) The APHA standard method for the enumeration of somatic coliphages in water has low efficiency of plating. Water Res. 34 759-762.

GUELIN A (1948) Etude quantitative de bactreiophage de la mer. Annu. Inst. Pasteur. 74 104-112.

HARM W (1980) Biological Effects of Ultraviolet Radiation. Cambridge Univ. Press, Cambridge, Mass.

HAVELAAR AH, VAN OLPHEN M and DROST YC (1993) F-specific RNA bacteriophages are adequate model organisms for enteric viruses in fresh water. Appl. Environ. Microbiol. 59 2956-2962

HAVELAAR AH, FURUSE K and HOGEBOOM WH (1986) Bacteriophages and indicator bacteria in human and animal faeces. J. Appl. Bacteriol. 60 255-262.

HAVELAAR AH and HOGEBOOM WM (1983) Factors affecting the enumeration of coliphages in sewage and sewage polluted waters. Antonie van Leeuwenhoek 49 387-397.

HAVELAAR AH and HOGEBOOM WM (1984) A method for the enumeration of male-specific bacteriophages in sewage. J. Appl. Bact. 56 439-447.

HAVELAAR AH, HOGEBOOM WM and POT R (1984) F-specific RNA bacteriophages in sewage; methodology and occurence. Water Sci. Technol. 17 645-655.

HAVELAAR AH and NIEUWSTAD TJ (1985) Bacteriophages and faecal bacteria as indicators of chlorination efficiency of biologically treated wastewater. J. Water Pollut. Control Fed 57 1084-1088.

HAVELAAR AH and POT-HOGEBOOM WM (1988) F-specific RNAbacteriophages as model viruses in water hygiene : Ecological aspects. Water Sci. Technol. 20 399-407.

HAVELAAR AH, POT-HOGEBOOM WM, FURUSE K, POT R and HORMANN NP (1990) F-specific RNA bacteriophages and sensitive host strains in faeces and wastewater of human and animal origin. J. Appl. Bact. 69 30-37.

HAYES W (1968) The Genetics of Bacteria and their Viruses (2nd edn.) Blackwell Scientific Publications, Oxford.

HAYWARD K (1999) Editorial: Phages gain ground as water quality indicators. Water 21 (Magazine of the International Water Association), Nov-Dec, 36-37.

HILTON MC and STOTZKY G (1973) Use of coliphages as indicators of water pollution. Can. J. Microbiol. 19 747-751.

HSU F-C, SHIEH Y-SC, VAN DUIN J, BEEKWILDER MJ and SOBSEY MD (1995) Genotyping male-specific coliphages by hybridization with oligonucleotide probes. Appl. Environ. Microbiol. $613960-$ 3966.

HURST CJ, BENTON WH and STETLER RE (1989) Detecting viruses in water. J. Am. Water Works Ass. 81 71-80.

HURST CJ, BLANNON JC, HARDAWAY RL and JACKSON WC (1994) Differential effect of tetrazolium dyes upon bacteriophage plaque assay titers. Appl. Environ. Microbiol. 60 3462-3465.

IAWPRC STUDY GROUP ON HEALTH RELATED WATER MICROBIOLOGY (1991) Bacteriophages as model viruses in water quality control. Water Res. 25 529-545.

IGNAZITTO G, VOLTERRA L, AULICINO FA and D'ANGELO AM (1980) Coliphages as indicators in a treatment plant. Water Air Soil Pollut. 13 391-398. 
IJZERMAN MM, FALKINHAM III JO, RENEAU RB JR and HAGEDORN C (1994) Field evaluation of two colorimetric coliphage detection methods. Appl. Environ. Microbiol. 60 826-830.

ISO (1995) Water Quality - Detection and Enumeration of Bacteriophages. Part 1: Enumeration of F-specific RNA Bacteriophages. ISO 107051:1995. International Organization for Standardization, Geneva. 15 pp.

ISO (1998a) Water quality - Detection and Enumeration of Bacteriophages. Part 2: Enumeration of Somatic Coliphages. ISO/DIS 10705-2.2. International Organization for Standardization, Geneva. 17 pp.

ISO (1998b) Water quality - Detection and Enumeration of Bacteriophages. Part 4: Enumeration of Bacteriophages Infecting Bacteroides fragilis. ISO/CD 10705-4. International Organization for Standardization, Geneva. 29 pp.

JAGALS P, GRABOW WOK and DE VILLIERS JC (1995) Evaluation of indicators for assessment of human and animal faecal pollution of surface run-off. Water Sci. Technol. 31 235-241.

JANSONS, J and BUCCENS MR (1986) Virus detection in water by ultrafiltration. Water Res. 20 1603-1608.

JOFRE J, BLASI M, BOSCH A and LUCENA F (1989) Occurrence of bacteriophages infecting Bacteroides fragilis and other viruses in polluted marine sediments. Water Sci. Technol. 21 15-19.

JOFRE J, OLLE E, RIBAS F, VIDAL A and LUCENA F (1995) Potential usefulness of bacteriophages that infect Bacteroides fragilis as model organisms for monitoring virus removal in drinking water treatment plants. Appl. Environ. Microbiol. 61 3227-3231.

JOFRE, J, BOSCH A, LUCENA F, GIRONES R and TARTERA C (1986) Evaluation of Bacteroides fragilis bacteriophages as indicators of the virological quality of water. Water Sci. Technol. 18 167-173.

JOTHIKUMAR N, DWARKADAS A and KHANNA P (1990) A simple elution and reconcentration technique for viruses concentrated on membrane filters from drinking water samples. Water. Res. $24367-$ 372.

KAI S, WATANABE S, FURUSE K and OSAWA A (1985) Bacteroides bacteriophages isolated from human faeces. Microbiol. Immunol. 29 895-899.

KAPUSCINSKIRR and MITCHELLR (1983) Sunlight-induced mortality of viruses and Escherichia coli in coastal seawater. Environ. Sci. Technol. 17 1-6.

KATZENELSON E, FATTAL B and HOSTOVSKY T (1976) Organic flocculation: An efficient second-step concentration method for the detection of viruses in tap water. Appl. Environ. Microbiol. 32 638639.

KELLER R and TRAUB N (1974) The characterisation of a Bacteroides fragilis bacteriophage recovered from animal sera: Observations on the nature of Bacteroides bacteriophage carrier culture. J. Gen. Virol. 24 895-899.

KENARD RP and VALENTINE RS (1974) Rapid determination of the presence of enteric bacteria in water. Appl. Microbiol. 27 484-487.

KENNEDY JR, JJ, BITTON G and OBLINGER JL (1985) Comparison of selective media for assay of coliphages in sewage effluent and lake water. Appl. Environ. Microbiol. 49 33-36.

KESSIK MA and WAGNER RA (1978) Electrophoretic mobilities of virus adsorbing filter materials. Water Res. 12 263-268.

KFIR R, COUBROUGH P and GRABOW WOK (1991) The occurrence of male-specific and somatic bacteriophages in polluted South African waters. Water. Sci. Technol. 24 251-254.

KOTT Y (1966b) Survival of T bacteriophages and coliform bacteria in sea water. Bull. Inst. Mar. Sci. 11 1-6.

KOTT Y (1981) Viruses and bacteriophages. Sci. Total Environ. 18 1323

KOTT Y (1984) Coliphages as reliable enteric virus indicators. In: Melnick JL (ed.) Viruses in Water. Karger, Basel. 171-174.

KOTT Y, BEN-ARI H and VINOKUR L (1978) Coliphages survival as viral indicator in various wastewater quality effluents. Prog. Water Technol. 10 337-346.

KOTT Y (1966a) Estimation of low numbers of Escherichia coli bacteriophages by use of the most probable number method. Appl. Microbiol. 14 141-144

KOTT Y, ROZE N, SPERBER S and BETZER N (1974) Bacteriophages as viral pollution indicators. Water Res. 8 165-171.
LOGAN KB, REES GE, SEELEY ND and PRIMROSE SB (1980) Rapid concentration of bacteriophages from large volumes of freshwater: Evaluation of positively charged, microporous filters. J. Virol. Methods $187-97$.

MANILOFF J and ACKERMANN H-W (1998) Taxonomy of bacterial viruses: Establishment of tailed virus genera and the order Caudovirales. Arch. Virol. 143 2051-2063.

MARZOUK Y, GOYAL SM and GERBA CP (1980) Relationship of viruses and indicator bacteria in water and wastewater of Israel. Water Res. 14 1585-1590.

MONTGOMERY JM (1982) Evaluation of Treatment Effectiveness for Reducing Trihalomethanes in Drinking Water. Final Report EPA-6801-6292, US Environmental Protection Agency, Cincinnati, Ohio.

MORINIGO MA, WHEELER D, BERRY C, JONES C, MUNOZ MA, CORNAX R and BORREGO JJ (1992) Evaluation of different bacteriophage groups as faecal indicators in contaminated natural waters in Southern England. Water Res. 26 267-271.

MUNIESA M and JOFRE J (1998) Abundance in sewage of bacteriophages that infect Escherichia coli $0157: \mathrm{H} 7$ and that carry the shiga toxin 2 gene. Appl. Environ. Microbiol. 64 2443-2448.

MUNIESA M and JOFRE J (2000) Occurrence of phages infecting Escherichia coli $\mathrm{O} 157: \mathrm{H} 7$ carrying the Stx 2 gene in sewage from different countries. FEMS Microbiol. Lett. 183 197-200.

MUNIESA M, LUCENA F and JOFRE J (1999) Comparative survival of free shiga toxin 2-encoding phages and Escherichia coli strains outside the gut. Appl. Environ. Microbiol. 65 5612-5618.

MURPHY FA, FAUQUET CM, BISHOP DHL, GHABRIAL SA, JARVIS AW, MARTELLI GP, MAYO MA and SUMMERS MD (eds.) (1995) Virus Taxonomy: Classification and Nomenclature of Viruses. Springer Verlag, Wien.

NACESCU N, BRANDIS H and WERNER H (1972) Isolation of two Bacteroides fragilis phages from sewage and detection of lysogenic strains. Zbl. Bak. Hyg. Abt. Orig. A 219 522-529.

NARANJO JE, CHAIDEZ CL, QUINONEZ M, GERBA CP, OLSON J and DEKKO J (1997) Evaluation of a portable water purification system for the removal of enteric pathogens. Water Sci. Technol. 35 55-58.

NATARO JP and KAPER JB (1998) Diarrheagenic Escherichia coli. Clin. Microbiol. Rev. 11 142-201.

NIEMI M (1976) Survival of Escherichia coli phage T7 in different water types. Water Res. 10 751-755.

NUPEN EM, BASSON NC and GRABOW WOK (1980) Efficiency of ultrafiltration for the isolation of enteric viruses and coliphages from large volumes of water in studies on wastewater reclamation. Prog. Water Technol. 12 851-863.

OLIVIERI A, EISENBERG D, SOLLER J, EISENBERG J, COOPER R, TCHOBANOGLOUS G, TRUSSELL R and GAGLIARDO P (1999) Estimation of pathogen removal in an advanced water treatment facility using Monte Carlo simulation. Water Sci. Technol. 40223 233.

OSAWA S, FURUSE K and WATANABE I (1981) Distribution of ribonucleic acid coliphages in animals. Appl. Environ. Microbiol. 41 164-168.

PADAN E, SHILO M and KISLEV N (1967) Isolation of "cyanophage" from freshwater ponds and their interaction with Plectonema boryanum. Virology 32 234-246.

PAYMENT P, BERUBE A, PERREAULT D, ARMON R and TRUDEL M (1989) Concentration of Giardia lamblia cysts, Legionella pneumophilla, Clostridium perfringens, human enteric viruses, and coliphages from large volumes of drinking water, using a single filtration. Can. J. Microbiol. 35 932-935.

PAYMENT P and FRANCOE (1993) Clostridium perfringens and somatic coliphages as indicators of the efficiency of drinking water treatment for viruses and protozoan cysts. Appl. Environ. Microbiol. 592418 2424

PAYMENT P, FRANCO E and SIEMIATYCKI J (1993) Absence of relationship between health effects due to tap water consumption and drinking water quality parameters. Water Sci. Technol. 27 137-143.

PAYMENT P, TRUDEL M and PLANTE R (1985) Elimination of viruses and indicator bacteria at each step of treatment during preparation 
of drinking water at seven water treatment plants. Appl. Environ. Microbiol. 49 1418-1428.

PEDROSO DMM and MARTINS MT (1995) Ultra-morphology of coliphages isolated from water. Water Res. 29 1199-1202.

PELCZAR MJ (Jr), CHAN ECS and KRIEG NR (1988) Microbiology (5th edn.) McGraw-Hill Book Co, Singapore. 416 pp.

PRESTON DR, VASUDEVEN TV, BITTON G, FARRAH SR and MOREL JL (1988) Novel approach for modifying microporous filters for virus concentration form water. Appl. Environ. Microbiol. 54 1325-1329.

PRIMROSE SB and DAY M (1977) Rapid concentration of bacteriophages from aquatic habitats. J. Appl. Bact. 42 417-421.

PRIMROSE SB, SEELEY ND, LOGAN KB and NICOLSON JW (1982) Methods for studying aquatic bacteriophage ecology. Appl. Environ. Microbiol. 43 694-701.

PUIG M, PINA S, LUCENA F, JOFRE J and GIRONES R (2000) Description of a DNA amplification procedure for the detection of bacteriophages of Bacteroides fragilis HSP40 in environmental samples. J. Virol. Methods 89 159-166.

PUIG A, QUERALT N, JOFRE J and ARAUJO R (1999) Diversity of Bacteroides fragilis strains in their capacity to recover phages from human and animal wastes and from fecally polluted wastewater. Appl. Environ. Microbiol. 65 1772-1776.

ROSE JB, ZHOU X, GRIFFIN DW and PAUL JH (1997) Comparison of PCR and plaque assay for detection and enumeration of coliphage in polluted marine waters. Appl. Environ. Microbiol. 63 4564-4566.

ROSE JB, SINGH SN, GERBA CP and KELLEY LM (1984) Comparison of microporous filters for concentration of viruses from wastewater. Appl. Environ. Microbiol. 47 989-992.

SALYERS AA (1984) Bacteroides of the human lower intestinal tract. Ann. Rev. Microbiol. 38 293-313.

SARRETTEBA, DANGLOT CD and VILAGINES R(1977) A new and simple method for recuperation of enteroviruses from water. Water Res. 11 355-358.

SCHAPER M and JOFRE J (2000) Comparison of methods for detecting genotypes of F-specific RNA bacteriophages and fingerprinting the origin of faecal pollution in water samples. J. Virol. Methods $\mathbf{8 9} 1$ 10.

SCHEUERMAN PR, FARRAH SR and BITTON G (1987) Reduction of microbiological indicators and viruses in a cypress strand. Water Sci. Technol. 19 539-546.

SEELEY ND and PRIMROSE SB (1980) The effect of temperature on the ecology of aquatic bacteriophages. J. Gen. Virol. 46 87-95.

SEELEY ND and PRIMROSESB (1982) The isolation of bacteriophages from the environment. J. Appl. Bact. 53 1-17.

SEELEY ND, HALLARD G and PRIMROSE SB (1979) A portable device for concentrating bacteriophages from large volumes of freshwater. J. Appl. Bact. 47 145-152.

SELNA MW and MIELE RP (1977) Virus sampling in wastewater-field experiments. J. Environ. Eng. Div. Am. Soc. Civ. Eng. 103 693-705.

SHAH PC and McCAMISH J (1972) Relative chlorine resistance of poliovirus I and coliphages F2 and T2 in water. Appl. Microbiol. 24 658-659.

SHIELDS PA and FARRAH SR (1986) Concentration of viruses in beef extract by flocculation with ammonium sulfate. Appl. Environ. Microbiol. 51 211-213.

SHIELDS PA, BERENFELD SA and FARRAH SR (1985) Modified membrane-filter procedure for concentration of enteroviruses from tap water. Appl. Environ. Microbiol. 49 453-455.

SHIELDS PA, LING TF, TJATHA V, SHAH DO and FARRAH SR (1986) Comparison of positively charged membrane filters and their use in concentrating bacteriophages in water. Water Res. 20145 151.

SIMKOVA A and CERVENKA J (1981) Coliphages as ecological indicators of enteroviruses in various water systems. Bull. World Health Org. 59 611-618.

SINGH SN and GERBA CP (1983) Concentration of coliphage from water and sewage with charge-modified filter aid. Appl. Environ. Microbiol. 45 232-237.

SINTON LW, FINLAY RK and REID AJ (1996) A simple membranefiltration-elution method for the enumeration of F-RNA, F-DNA and somatic coliphages in 100-m water samples. J. Microbiol. Meth. 25 257-269.

SNEAD MCV, OLIVIERI P, KAWATA K and KRUSE CW (1980) The effectiveness of chlorine residuals in inactivation of bacteria and viruses introduced by post-treatment contamination. Water Res. 14 403-408.

SOBSEY MD and GLASS JS (1980) Poliovirus concentration from tapwater with electro-positive adsorbent filters. Appl. Environ. Microbiol. 40 201-210.

SOBSEY MD, SCHWAB KJ and HANDZEL TR (1990) A simple membrane filter method to concentrate and enumerate male-specific RNA coliphages. J. Am. Water Works Ass. 82 52-59.

SOBSEY MD and HICKEY AR (1985) Effects of humic and fulvic acids on poliovirus concentration from water by microporous filtration. Appl. Environ. Microbiol. 49 259-264.

SPENCER R (1955) A marine bacteriophage. Nature 175690.

STANDARD METHODS (1998) Coliphage detection. In: Clesceri LS, Greenberg AE and Eaton AD (eds.) Standard Methods for the Examination of Water and Wastewater (20th edn.) American Public Health Association, Washington DC. 9-24 - 9-25.

STETLER RE (1984) Coliphages as indicators of enteroviruses. Appl. Environ Microbiol. 48 668-670.

STROCKBINE NA, WELLS JG, BOPP CA AND BARRETT TJ (1998) Overview of detection and subtyping methods. In: Kaper JB and O'Brien AD (eds.) Escherichia coli O157:H7 and Other Shiga ToxinProducing E. coli Strains. ASM Press, Washington DC.

STRAUSS JH and SINSHEIMER RL (1963) Purification and properties of bacteriophage MS-2 and of its ribonucleic acid. J. Mol. Biol. 7 43-54.

STROHMAIER K (1967) Virus concentration by ultrafiltration. In: Methods in Virology. Academic Press, New York. 245-274.

SUGIYAMA T and NAKADA DJ (1970) Translational control of bacteriophage MS2 RNA cistrons by MS2 coat protein: Affinity and specificity of the interaction of MS2 coat protein with MS2 RNA. Mol. Biol. 48 349-355.

SWEET BA, ELLENDER RD and LEONG JL (1974) Recovery and removal of viruses from water utilising membrane techniques. Develop. Ind. Microbiol. 15 142-159.

TARTERA C, LUCENA F and JOFRE J (1989) Human origin of Bacteroides fragilis bacteriophages present in the environment. Appl. Environ Microbiol. 55 2696-2701.

TARTERA C, ARAUJO R, MICHEL T and JOFRE J (1992) Culture and decontamination methods affecting enumeration of phages infecting Bacteroides fragilis in sewage. Appl. Environ. Microbiol. 58 26702673.

TARTERA C, BOSCH A and JOFRE J (1988) The inactivation of bacteriophages infecting Bacteroides fragilis by chlorine treatment and UV-irradiation. FEMS Microbiol. Lett. 56313.

TARTERAC and JOFREJ (1987) Bacteriophages active against Bacteroides fragilis in sewage-polluted waters. Appl. Environ. Microbiol. $\mathbf{5 3}$ 1632-1637.

UYS M (1999) Molecular Characterization of F-specific RNA Phages in South Africa. MSc Dissertation, University of Pretoria, Pretoria.

VALENTINE RC and ALLISON AC (1959) Virus particle adsorption. I. Theory of adsorption and experiments on the attachment of particles to non-biological surfaces. Biochim. Biophys. Acta 34 10-23.

VAUGHN JM and METCALF TG (1975) Coliphages as indicators of enteric viruses in shellfish and shellfish raising estuarine waters. Water Res. 9 613-616.

VILAGINÈS P, SARRETTE B, CHAMPSAUR H, HUGUES B, DOUBROU S, JORET J-C, LAVERAN H, LESNE J, PAQUIN JL, DELATTRE JM, OGER C, ALAME J, GRATELOUP I, PERROLLET H, SERCEAU R, SINÈGRE F and VILAGINÈS R (1997) Round robin investigation of glass wool method for poliovirus recovery from drinking water and sea water. Water Sci. Technol. 35 455-460.

VILAGINÈS P, SARRETTE B, HUSSON G and VILAGINES R (1993) Glass wool for virus concentration at ambient water $\mathrm{pH}$ level. Water Sci. Technol. 27 299-306.

WALLIS CM, HENDERSON and MELNICK JL (1972) Enterovirus concentration on cellulose membranes. Appl. Environ. Microbiol. 23 476-480. 
WENTSEL RS, O'NEIL PE and KITCHENS JF (1983) Evaluation of coliphage detection as a rapid indicator of water quality. Appl. Environ. Microbiol. 43 430-434.

WEST PA (1989) Human pathogens and public health indicator organisms in shellfish. In: Austin B and Austin DA (eds.) Methods for the Microbiological Examination of Fish and Shellfish. Ellis Horwood, Chichester. 273-308.

WHO (1993) Guidelines for Drinking-Water Quality Vol 1: Recommendations (2nd edn.). World Health Organization, Geneva. 188 pp.
WHO (1997) Guidelines for Drinking-water Quality. Vol 3: Surveillance and Control of Community Supplies (2nd edn.) World Health Organization, Geneva. 238 pp.

WHO (1996) Guidelines for Drinking-Water Quality Vol 2: Health Criteria and Other Supporting Information (2nd edn.). World Health Organization, Geneva. 973 pp.

YATES MV, GERBA CP and KELLEY LM (1985) Virus persistence in groundwater. Appl. Environ. Microbiol. 49 778-781. 